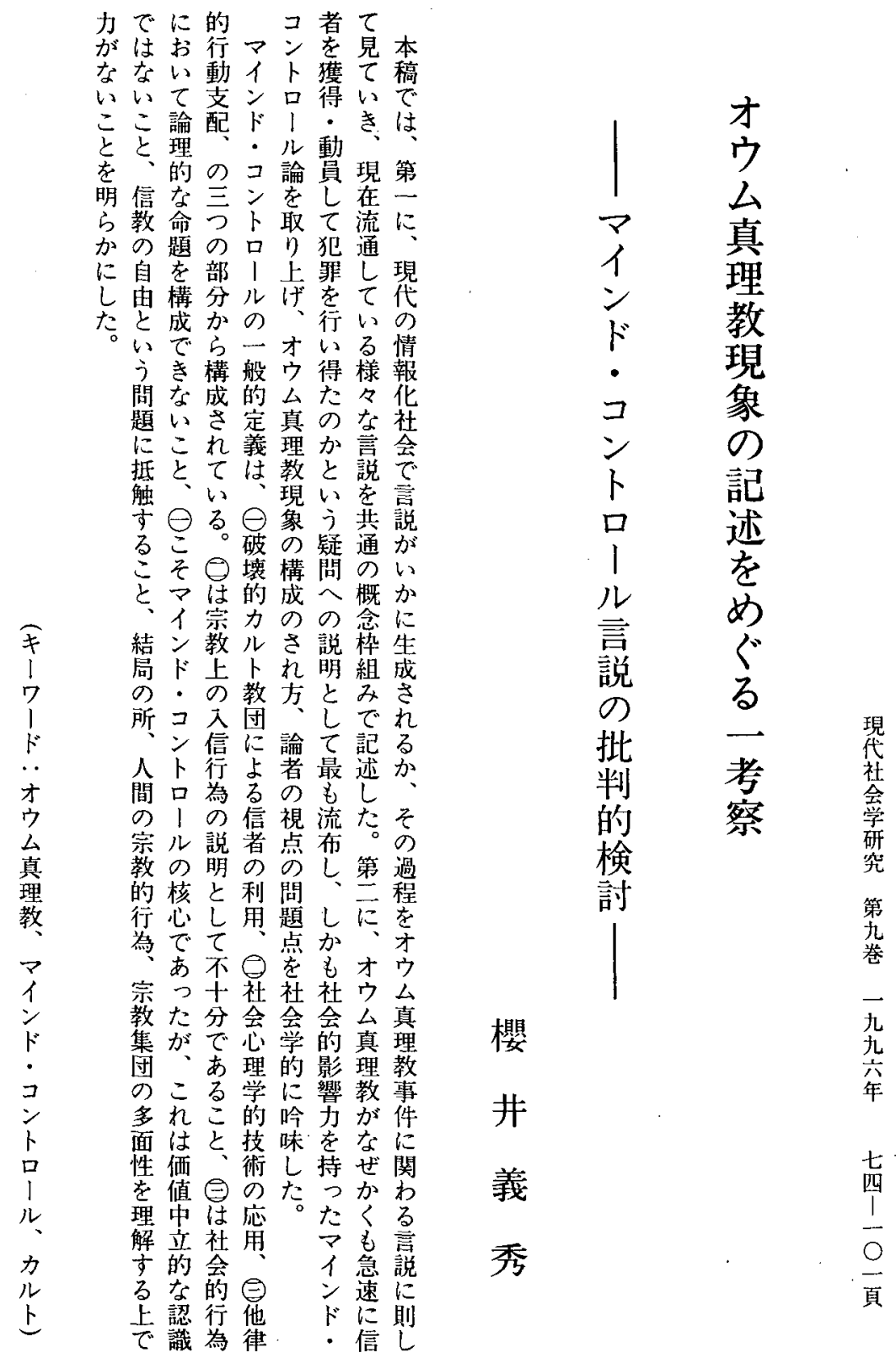




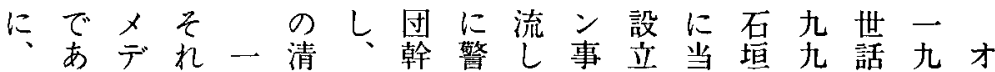
メるイぞ九算二部察て 件して島 $\bigcirc$ 役入ウ デかアれ九が二庁いのてて七年で九ム 1を情の五進月信長る裁事、ミ、西年真 ア知報才年め一者官間判業熊十麻つに理 やらかウはら九ががに所に本!原た東教 宗し ら厶材れ日多狙宿乗県をが坂京教 教め才像ウて宗数撃同舎り波開卖本都団 評るウを台い教逮さ年襲出野催真弁では 論た台作真名法捕れ言撃し、村し理護宗 家め真り理。人さ、有、に、党士教麻 がに理上教法れ重東つ上山千索法原 与こ教げ事に鹪京なラ梨人結家人彰 えのがて件基裁を地がブ県余成がの晃 たよいきに年判真下るル上り成拉認教 才方かた関くが鉄。を元の東致誕祖 ウななっわ 厶八る事る 真 デも件 情 理 1 の $の$ 報 教アで当が の空市事洪

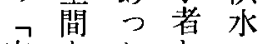
宗をたとの 教 利方上 的用をて 方 特卞推、事 質 術泪実 ををるそ1 知しの 伝つ兄它 統てなの間 とない。触流 乙我方出出

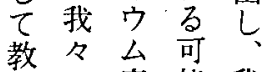
義の真能 我 社理 性 々 儀会教をは 礼的は持々 に認自たれ 取知分なら りをたいの 込得ち民報 みるがの道

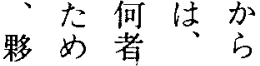

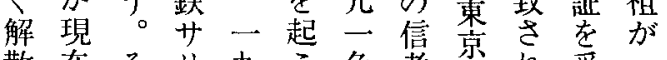
散在そり九こ色者尔れ受二 命隽のン九し村を老艺け九 令行後事五て等動㐫ジた公 が中件年はに員菜や宗四 確で両が、告教し議! 教年 定古発茥訴罗た院十団に 敬る生りで施。選り体結 教。关关解設以举スで成 団二事恎毒決を. 後に上あし 関云件事吕し建信出江るた 係局に不設者䔍川。妇 事一假な容j總劣紹一1 件五谷る疑と住出る子九 の日さ。でし民家方、八サ 被政え警警てと惨日九! 害府拉視察: 对勧惨并年》 者は致庁がこ立め敗連一ル の才事は内の弯てそが二 損ウ件教偵やる。々 独具方

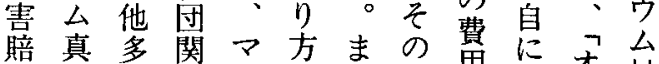
償理数連スがた持角調オ神 請教の施 コ一弆借查公仙

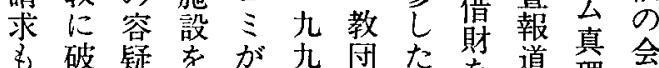

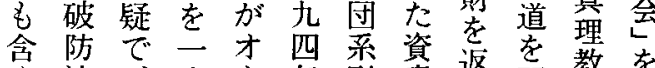

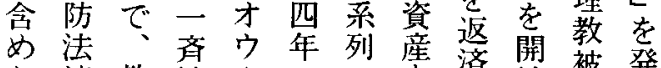
た適教捜㕕のの璱始被発

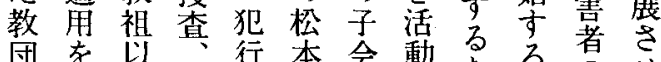
団老员四行本会動るる。の者管

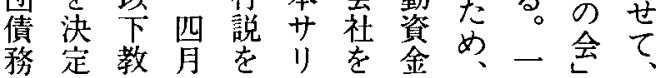




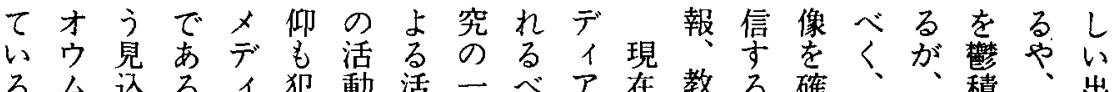
る厶这る。犯動活一航? 在教る確、積今出 の真み。ア罪内動般き。団情定さ社さ今版 で理も現を行容事的問世才活報专荟せ度物 あ教少段通為は実な題論门動とるに的てはを るのな階じへ検の方でが台停作誇評い亦刊 事いでての察確法市形真歨教業大価つガ行 筆実。こ報関に定でり成理以団はなのたた 者でオの道わよ等は、守教後に、宣 反と保 ははウ事さり竞宗るをは新才伝作考ブ地 オな台件れかて経教教才めメ抗ウ活用えなで ウい真をる。ら明て団研ウぐデし允動もら牙講 台。理生。之ら、活究台る代た真队まれウ演 真し教み要のか初動の真論 理加击出妥にめへ沵理点に域教硬大る。像老 教しめしる当さての外教はよ隹が姿きメに開

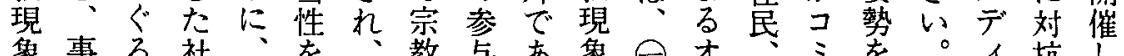

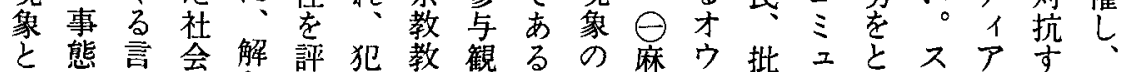

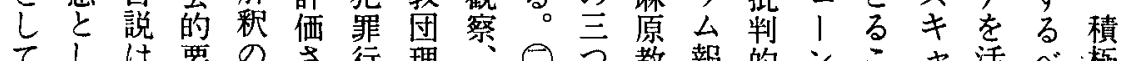
こしは要のさ行理、 $\ominus$ 教報的ンこャ活心゙極

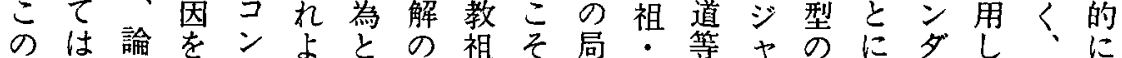
事こ者確示方し第解面幹宁!閉なラて力自

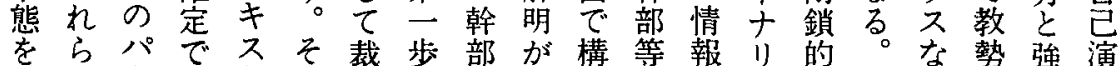

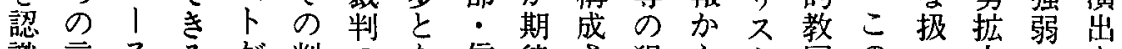
識言スるが判のな信待さ犯ら卜団のい大接を

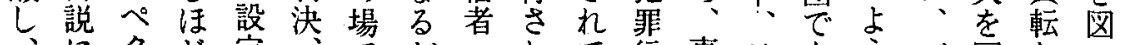

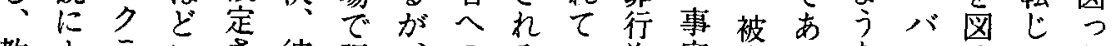
教よテに方彼評、のるい為実害つなッるてた

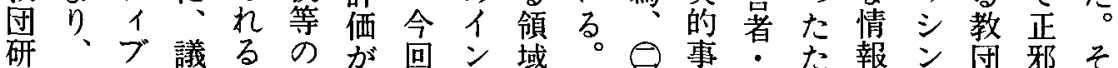

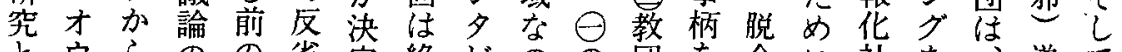

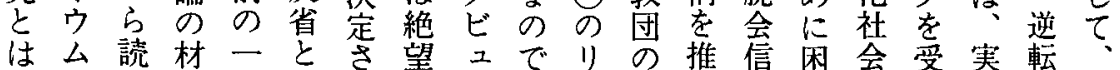

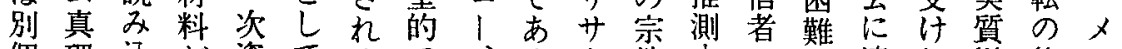
個理込が資てるる゙㐎教子す势適れ以終デ に教ま揃料の。あ教が手組る弁あ応ば上末1 はれう的教まる団、・織し護つし に観

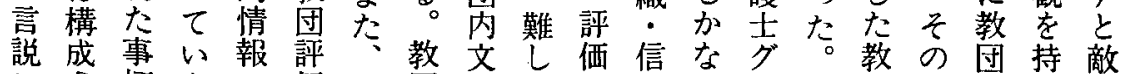
レさ柄なの価彼団書いは者いル事団評のつ対 べれない入自等の早司の状、実の価力儿的 ルのしし手貝の中聞宗直信態 プ等ををサな の批で、が惫核き教に仰でか教身否誇ン関 分評あ今不評想的取教委市方団大定示手係

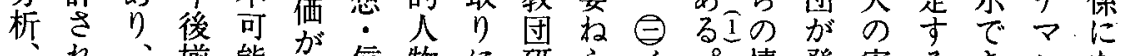

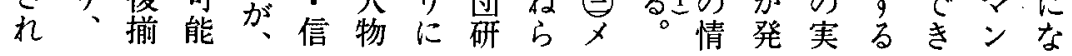


的いされう第す数に表

で○れると一るによ現.人

な、言た情すに能産り专は

以説殂報当出再る様

言の界の。包老構。名

説説像内こ括超れ成々な

が明ででこ的充され形

実力あ、でなて流れは態

には方は比通たパの

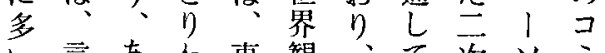

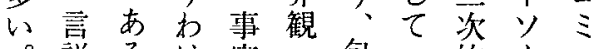

説令世赛

構に世界事欲的啝事ル二

成と観唡求なそ孝

しつにとが世の情デシ

たて関区起界压報 1 ヨ

主のわ別こ観倒とアン

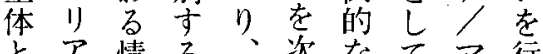

と, $\boldsymbol{T}$ 情 る 瓷なて行

、少報意様第情送ス方

言テ味名に報受・た

説、イ言でな構量信メめ

には説、情成は夺デに

よ別と個報し得個る

説人て乞りな人現共少

明の定べ।いが代にジ

さリ義ルス状事の使十

れアしでへ況実社わル

るリた市のが的会れな

客玄秋了出事空る事

体イ。ク現柄間が実

とで第集七する社に双出

関あに市を。会等来

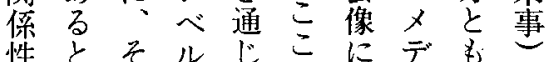

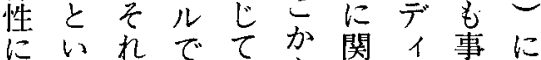

相う方自ら专宁柄関

関のれ分一るのにわ

寸主言尔多発関る

る観説発りの元達卞事 性は信の事的にる柄

こが断さ世事なよ解を

の保版彺界態情り釈社

点証的像生報情的会

に点に受を生を報枠空

自れ形容作忌処赫間 賞な成さろる理無みに
れ最第わ社社 方蓅に音会会

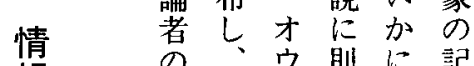

報視しム㲘訔述

化点加真元説

の毛理見肪し

問 社 教 $\tau$ 生

題会がい成そ

点的なきされ

社影ぜ現れる

会意等在そ妥

学をも流れ当

的持急通に性

につ速しよの

吟たにて?検

味 信いて 証

しイ者る社が

たンを様会必

いド獲名的要

- 得な事な

コ・言実の

ン動説がで

卜員を構は

口乙共成な

）通さい

ル犯のれか

論 罪 概て と

をを念き考

取行枠た之

り組かる。

上得みでそ本

の記の稿

才か述過で

ウとす程は

ムいるを

真 j 構才第

理疑成ウ一

教問図台に

現へ式真

象のを理 現

の説提教代

構 明 示事 $の$

成と守件情

のしるに報

巳 $\tau$ 。関化 
てな文舞のまる取上うたをいい的るで関

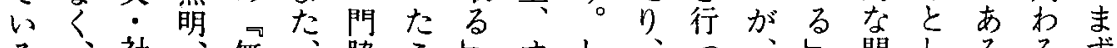

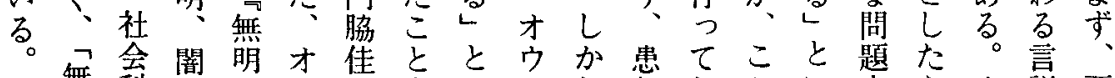

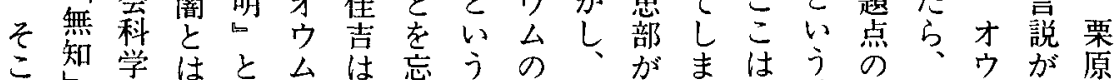

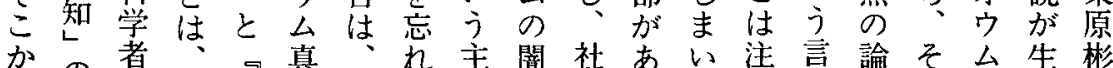

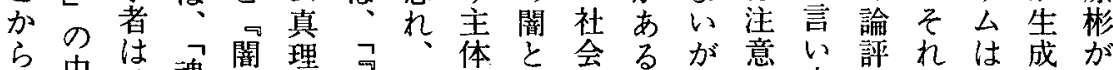

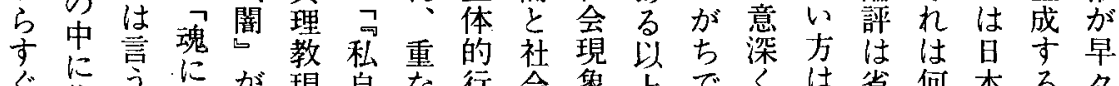
ぐ住方占が現自な行会衰上でくは省何本る々

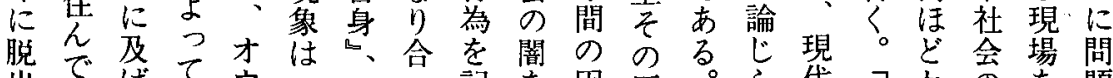

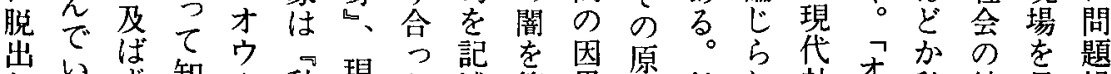

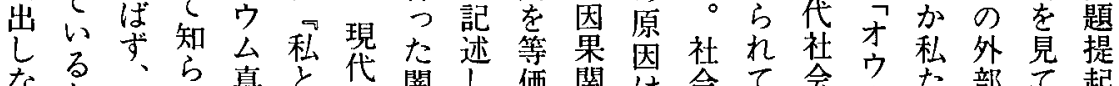

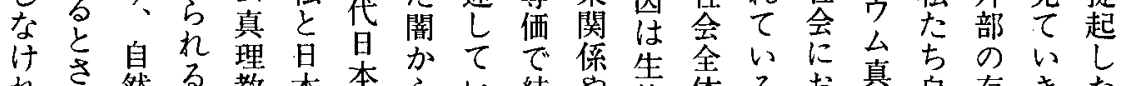

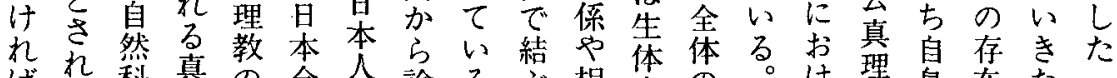
ばる科真の全人諭るぶ相内の。け理身在た

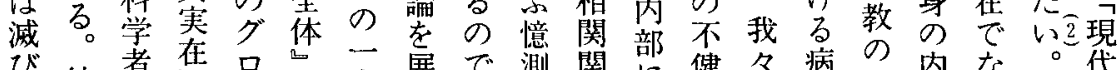

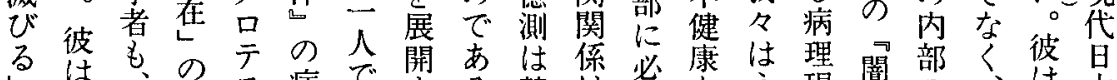

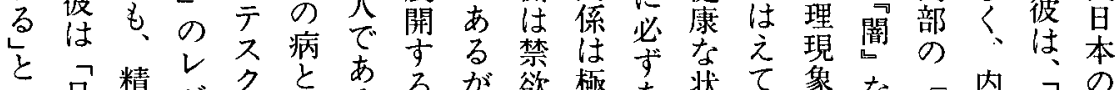

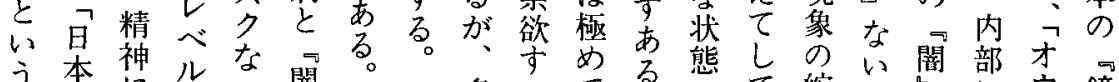

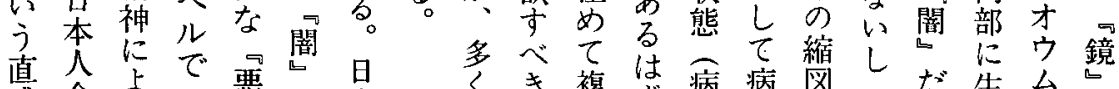

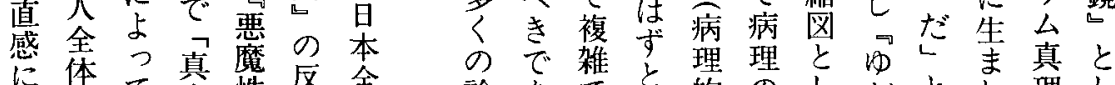
基のて知実性映全諭あでと的のしがとれ理し

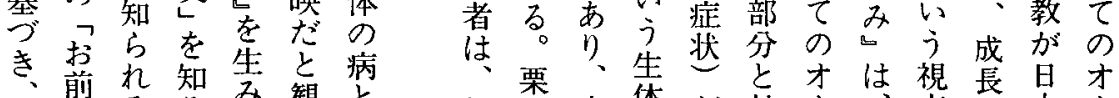

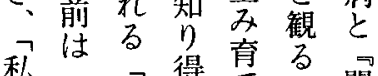

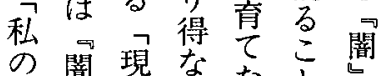

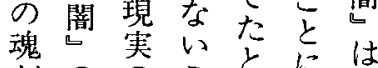
がのことには ぞ中感气言し私 のに賞でで鼻 集盟曹良主身

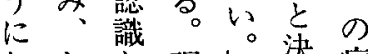
し 打它現产決病 前本在事心 自の質の㦔、䦔 分魂的昆篦

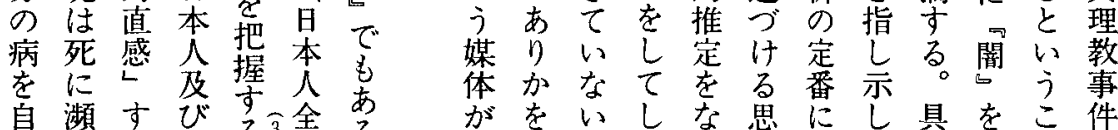

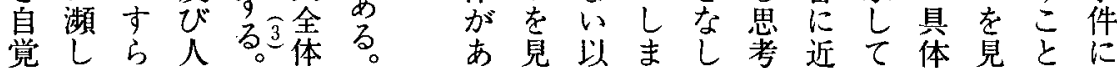


部教た勢よなさのへ

では時をう価れ社の山 妥、期搪な值衫会距折

当世に大理観ば的離哲 性俗は古解にな行・の雄 がの、るが支ら為取は 保常当た有之なの.り才 証識該め効らい理”方ウ さを宗になれが解にム れ越教、のて、に無報 る之の世はいジ従頓道 たた内俗、る十之着が めや的の教か、ばで言 にり世倫団ら十、あ説 方界理の、社り的 世で観やラ常ズ会、性 俗自組イ軌么文な格 的芑価織 フをに経㧍を なと值運サ逸は済か濃 合社観嫦 $九$ 前的つ厚 理会にのクた者な無に 性云従諭儿狂の利宗持 や变つ理で気視害教つ 倫革 $\zeta い$ 点関をて 理を教す之病が係自い 性企団りぼ理突と認る $\zeta$ 組 合出出点 相る織わ拡しし内な学 入。はせ究てて面が取 れ之活を牙い的らり

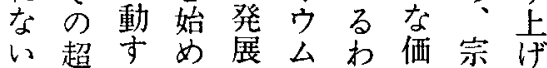
こ越るる期真计值教て との。段理でに報い も念間でな階す教あるる道るむ 并にあ扱。動行 得方未方方机機つデ る。法だ。付て 才飼教教とも、のる関 ウ宗慣ががなこ両と係 台教ら教世界面高者 真的さ団俗。眼吕る。

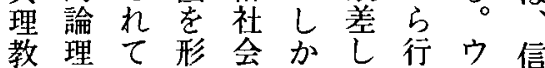
は構い成丙しは為工仰。 ま成なし部っ世は! さのい始でこ俗理バ信 に内宗め教の的解 | 条
いし热しにるいる引と営 の識していそ受みそ 事をか才うのけに 唡持語ウ事こるはか にてれム実とかコら 必ななの認はどうど ずいい闇識今うのの しこしをは一か論よ もと、生異つは理う

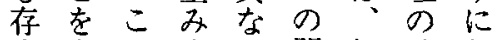
立事文出る。非個飛し 根彼脈た仮にのが癒 起はでのにも主あき 持無閒と事阑性る，帒

た明脇い実守自一い なっう認る自つつ いで決関識。由はた 説意連と才の. 既の そ明そづしウ問にか れしのけて么題述を 自よもがそので心忠 体うの必の闇あた実 でとと要よにる。代 閉孪しに方社。私辿 じるなに会社しる た。語る語の会と会 説これ。る䦣のい作 明のば無のを闇 う業 図反よ舞で読が主を 式証い明あみそ体始 でのこは记込の介め あ余と代むま在る る地で私、とまのの 言があな社い私忘で 説なるり会门の・却市 とい。主闇。る し完し読 心体に社 て全かみ的繋会こ 位なし这な行がのの 置 説、んる為つ闇極 づ明他だ䦣とてをめ けに者社の、い私て がはが会部反るの良 京々 の分映の闇心 さ事の記㔔し.でと的 わ実よ述いてはとな 


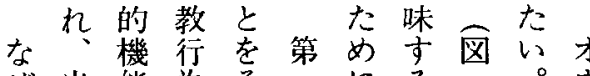

ぜ当能為そ一にる二。ウ三

ががれの必要こ主

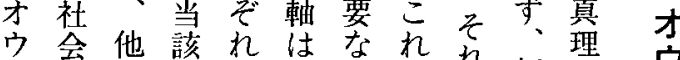

厶市の 社 対作ら厹新教

真ルあ会照宗業はぞ等事

理 1る台さ教で策教件

教儿種らせ性あ本言船が

に・の逸る とる 稿言船様

多制 社脱。世自説の航

数度会迕第 俗

の各行 て 云性

若ら為Wの

者独とる軸す

が立代とにな

入し替いはわ

信た可 う 行 能意宗 、 象 る

為で味教宗市次念の

教のあで行教市次染よ

祖基る の為の組

の準こ暴が論位みに

命をと質他理

に持を性の .

従つ指を社言

つて卞対会語

てい。照行に

る逸学為よ

反状脱せとる

社態とた類説

会をは。似明

的指文類 L

な活。為とい宗

動者はる 教

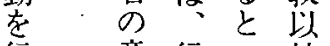

行意行w外

$\supset$ 識為うの

た がの 意 論

の 当主 味 理

か。該観で立

。社的 の 言

こ会な同語

の か 意質に

問 ら味性よ

心 切文名

を断社会説
る 徽㡖 説

分列認に

析烈識上

奶挙 市?

ン 音と䚺

- 琵てささ

コ唯二て

卜䈯つい

ロ办の

1る軸

儿辛侖角か、

論間角々

位空ての

置間言地

をを説平

相社空と

対会間 し

化的をて

才に四の

る考つ言

見察の説

取し象 空

りた限間

図言にを

を説分記

作を割述

る 吟 L L
主特活高

ド 空し識
をの期破るこ 包教を堙 方の 括団確活法段 し内定動が階 てでしに適で 納のて傾切破 得地いいで局 で位つたあまま き等た要るで るに島因。突 よ応溒をそき うし進探の進 なてのつ点ん 世作て誌だ 俗宗業い、と 的教 がる才考 説的的中方 明理を沢么ら は解得新版礼 なとて て る る い社いの|の の会る。分分がで で関。析 理 あ係 要や論な る 論 卞 合の お 的 る 教 特 さ 理に団街ら 解出出 を教 版ら 宗 バ義物 グ 教 ラ 加ル的 ン教ら麻世 ス 祖 教原界 よ 教之観 使団変者实 うの遷の践 こ特花 階 と 質 後 梯 ら が 付 構 教 必教计造団 要団、活 での 教 教 動 あ発団団の つ展活の展 て段動非開 そ階の较産理 れ信 換 性 解 ら者時守 
世俗性

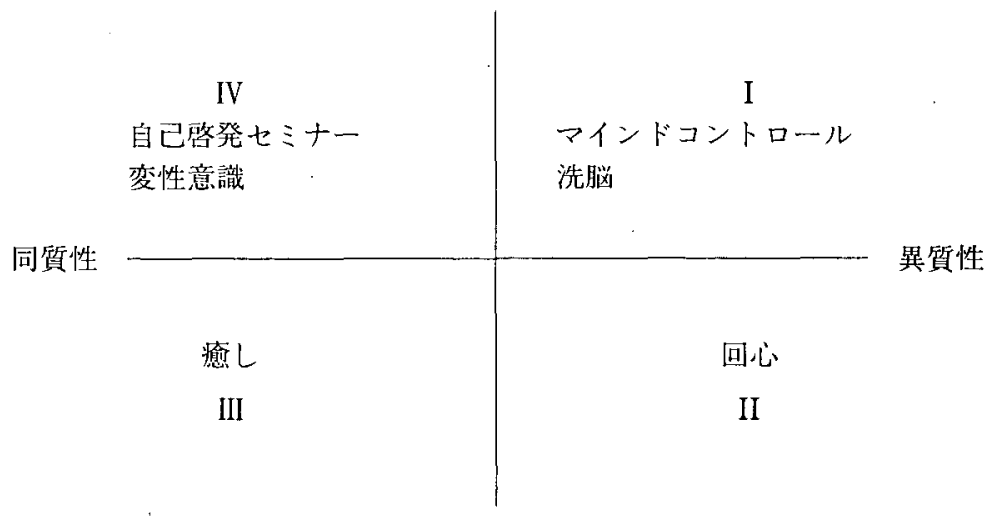

宗教性

図 1 言説の空間構成モデル

てもにい二宗も同宗のにけさ息析儿型象の宗 活が方こ象教当椂教力離れ我莪花限変教 力人ると限的該、にリ宗れた変社対さご容の を生とでのな社マは、教た意容会応れとと入 取のいあ回茾会イ世令的も識穴病专るにい信 り折うり心ブにン俗的回の状世理る。同う行 戻々意、と力対ドと誘心に態俗論。第导事為 子に味むのル抗・は因がな等的をマ一事象に の癒でし相千的コ別、入る本理初イの象.と見

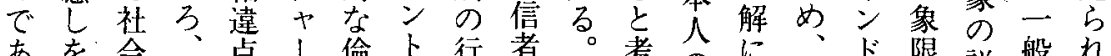
あを会、点!倫卜行者。考のに早限説般れ

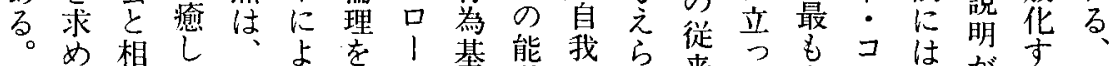
恒る補に現る持儿準動のれ来た人之名異る自

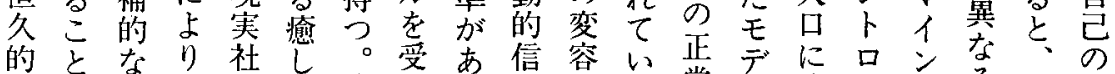

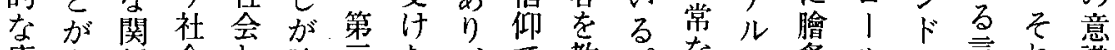

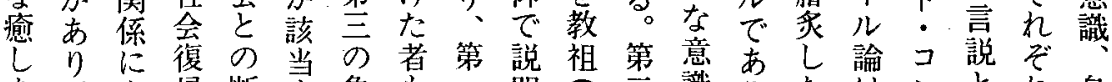
を、市帰断守象も一明指光識りたはンとれ身 希.瘉る老絶る限信のす㸃のと、宗精卜し四体 望さ。可が。に仰象る迸象は支教神口てう感 しれ誰能な第は者限。者限加配的分।類の賞 


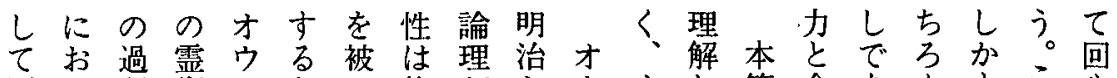

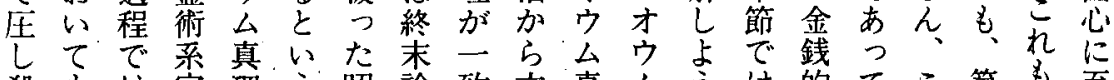

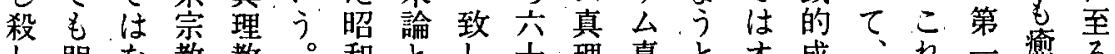

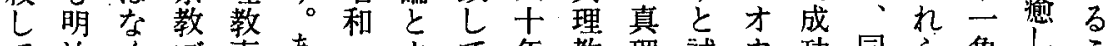

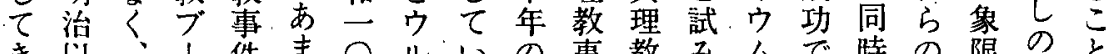
き以、门件ま

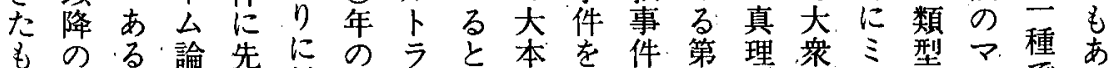

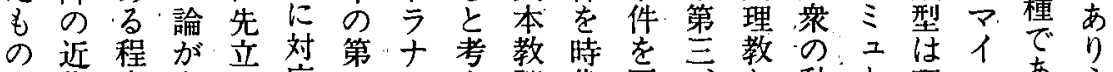

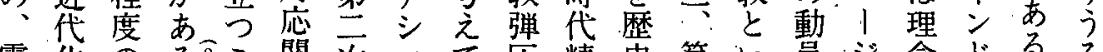

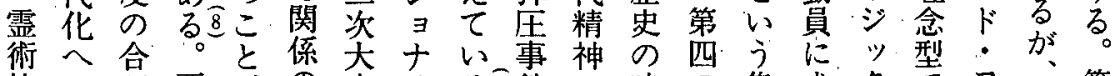

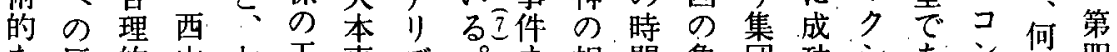
指 発思 は 年夫的 事

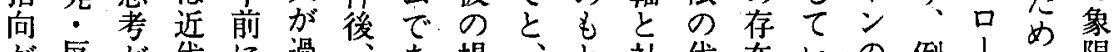
が反が代に過市場、祈代在いの例! に限

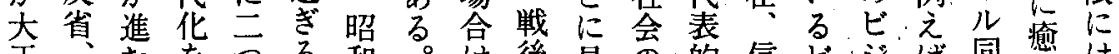

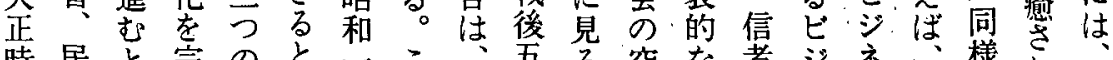

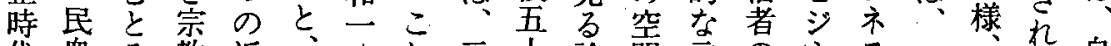

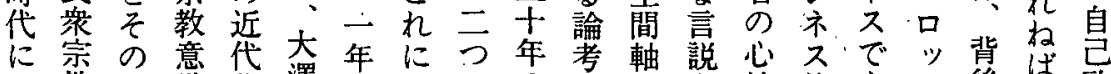

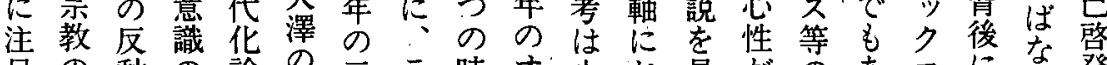

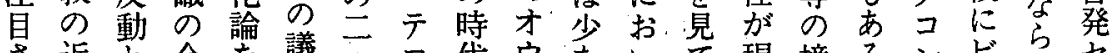

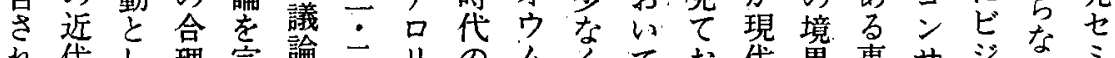

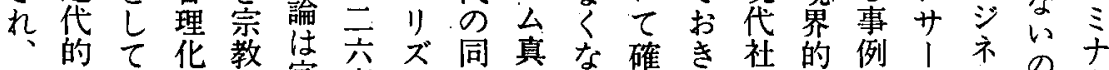

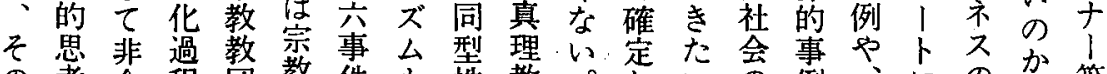

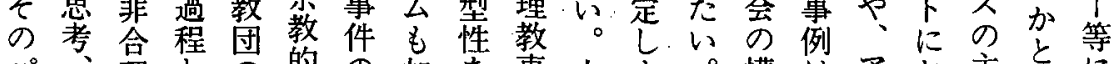
パ、理との的の 加を事大る。構はア㧧々に 夕信的措類摄 テ之周件澤方こ造多允け体うよ

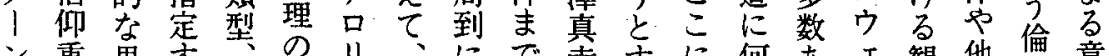

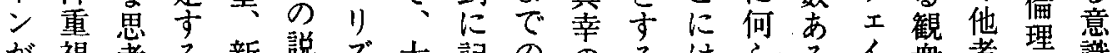

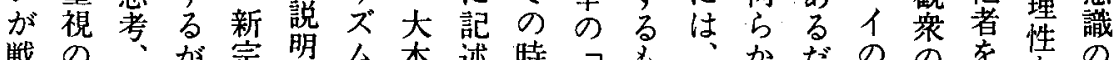
戦の、が宗明么本述特鸟、かだののをを性の

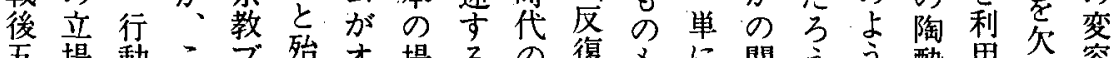
五場動こブ殆才場る。の復もに関う。方酔角以容

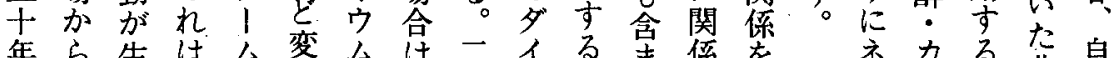

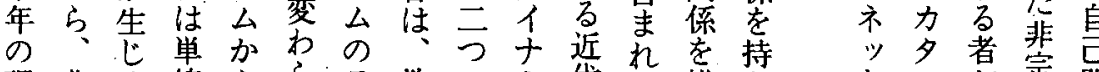

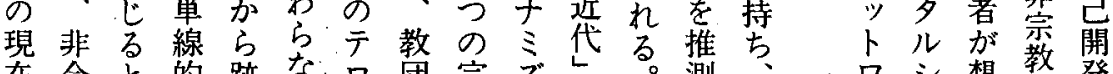

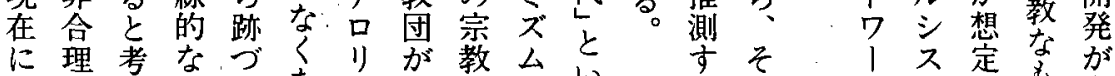

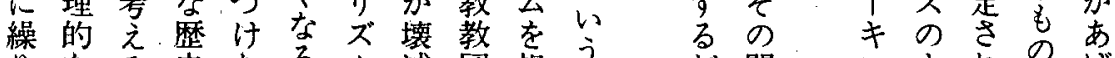
クなる史たる。滅団替主義だ関ンるれで゙

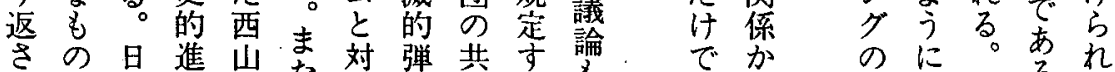

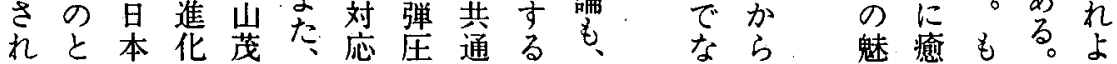


現はこ間合ゆのたらてする。象ウ意のおて し在长方る自現れ捨る。限次㕕識系りい

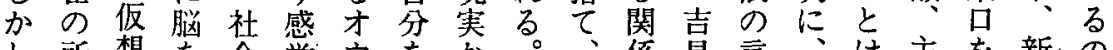

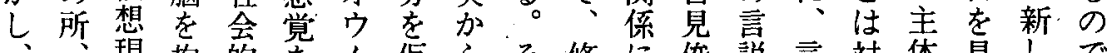

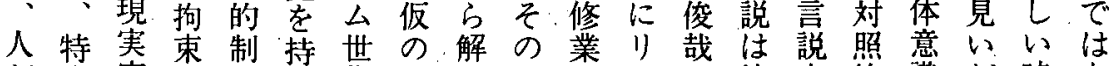
が定空李度つ，代姿放よのアに特空的識。だ時な 特の間る。たのとしう、行りょに間なをす間い

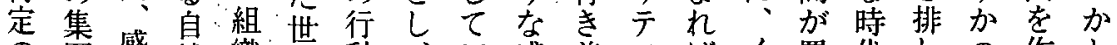
の団感然織代動、ビ感着人住置代しの作と

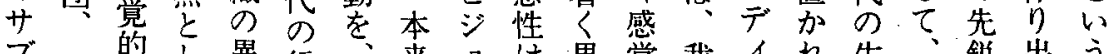

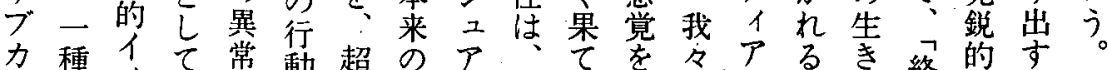

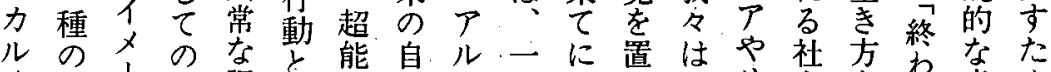

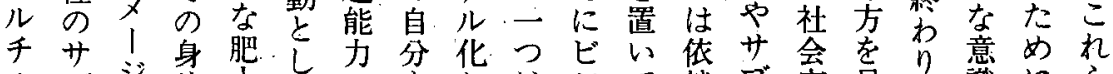

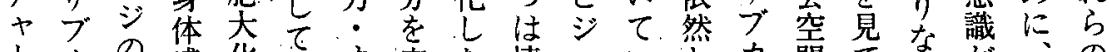

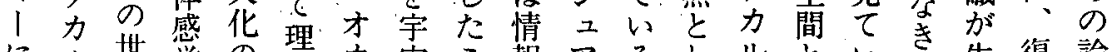

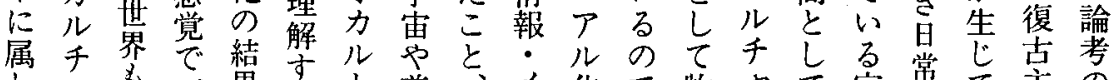

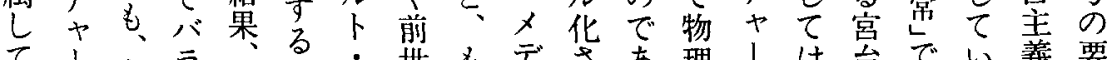
てに身う这世方世デさあ理! は台でい義要

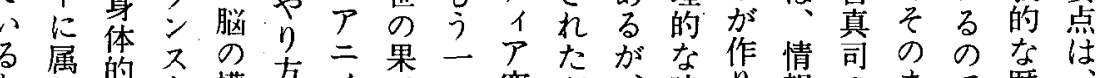
とし的在構方文果二究たがな作情司ののなは

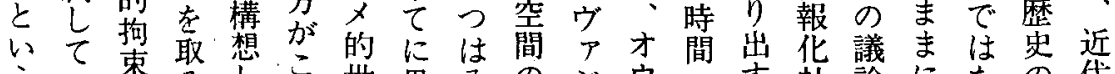

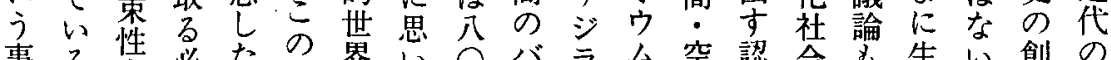
事る性必た界い○バラム空認会导生い創の

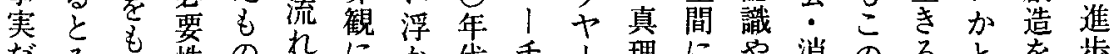

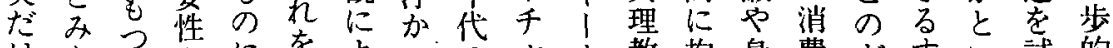
けな現がにをなら゙のヤ十教拘身費ヴすい試的

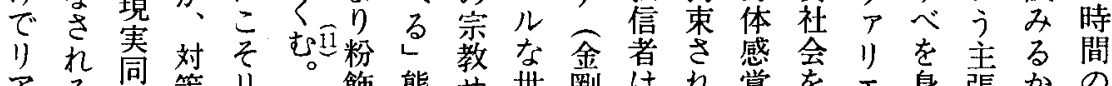

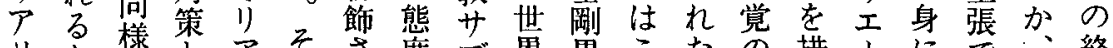
リと様とアそさ度ブ界界こたの措、にで、終

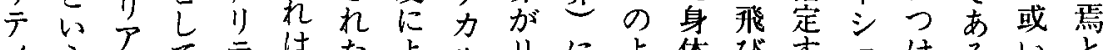

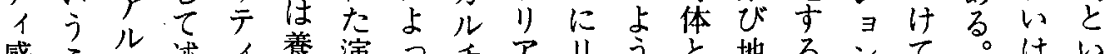

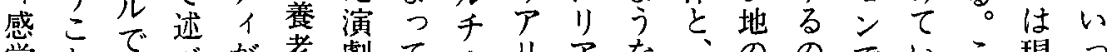
賞とあ心゙が老劇てャリアな、ののでいこ現つ のであら：孟空用、テリリそ存があるの代た

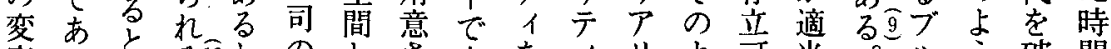

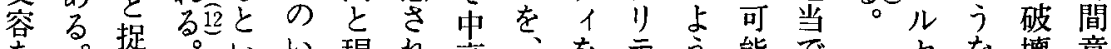
を。提。いい現れ高を离意

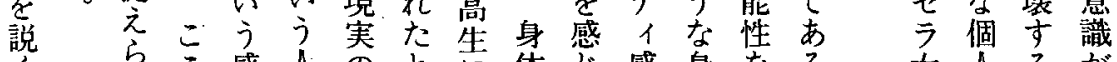
く れこ感人のと体に感身をる 女人るが の机で賞工空述流的て賞体問。子小こ社

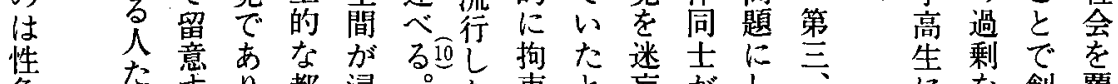

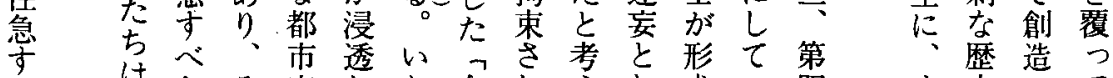

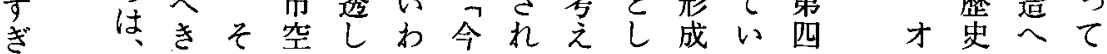




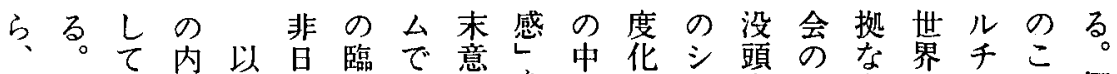

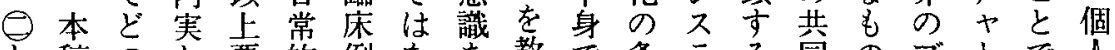
稿のと要的例な孝で条孝る同のブ।で人 ○程し約なかく徹団あ件么諸性と、はあの

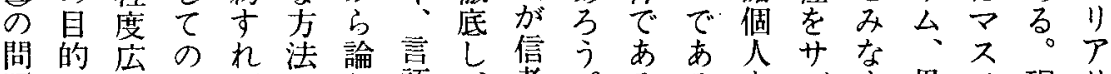

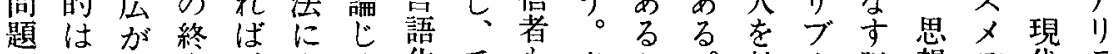

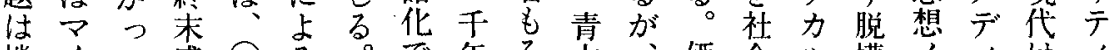
機イて感 $\ominus$ る。で年ろ条、価会儿構メイはイ 会ン心 をドる不ブ決かな国毛注界は共やの们にデ維

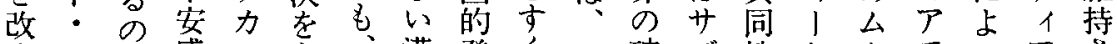
めコか感儿刍之漠発くバ破ブ性と|でつアさ てンを手と学想いブ局力にしドはて空れ

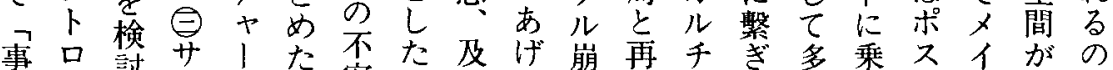

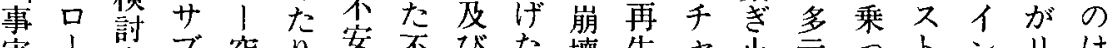

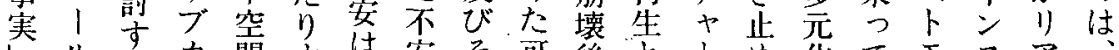

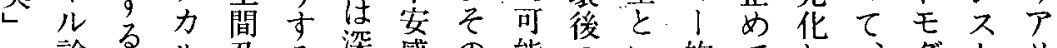

の論るル及染感の能のい的てし、多市他 検をとチびと居と蕉性日广現おた歴ンリ者者

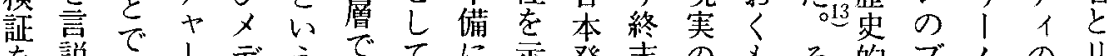

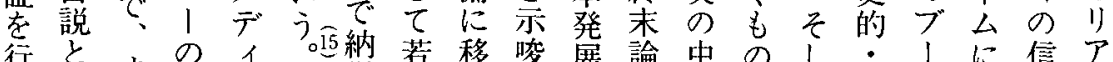

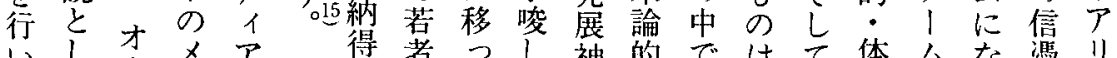

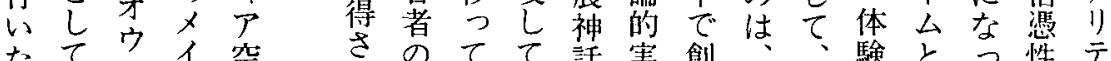
たてウイ空さのてて話実創、験とっ性テ

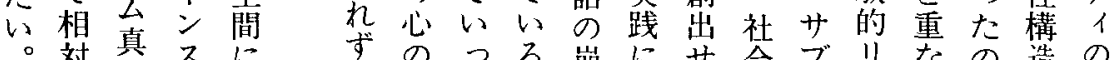

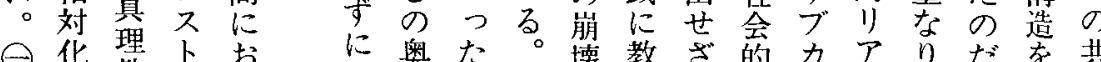
保奥た。壊教ざ的力ア りだを共

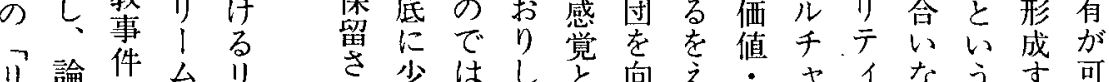

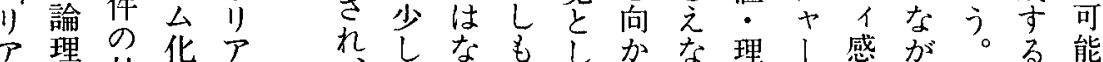

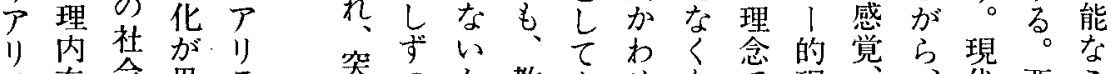

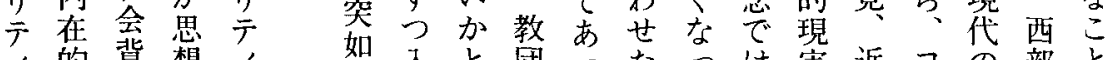
イ的背想1破入と団つたつは実近コの部と のに景的感破りいのた要たな空代ン文遇を

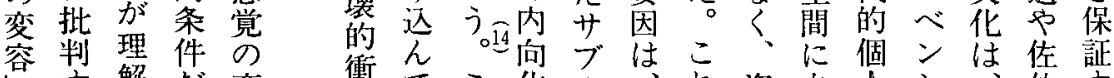
寸解だ変㗢でこ化力、れ資自人ジ伯寸 のるでけ容動いののルやは查閉のヨ宗啓る 問こきで方吉時千はサ主し概ナ教思信 題々合な はにとくサ茾慟なとはサカ・私をなデよ性

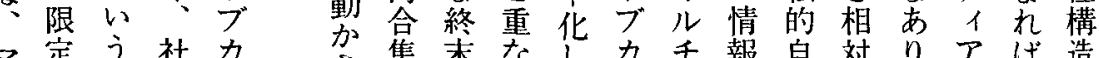
マ定う社力さ集条なし力千報自对りアば造 イさこ会ル雄感つたルャメ己化方で点

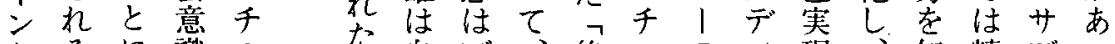
ドるに識ヤ䝵ブ、終ヤのイ現、無精ブつ 一かなと、方|終末，制アに社根神力て 
のけのが情達のに自メは教望 マ四 律と報倫に可会他を情外いイ— 性共を理対能的者適厂報のつン をに仕的しに権や合のの領たドマ 損六なてし威社さ拘内域問: 亿 な社往コ主たに会せ束容で題コン

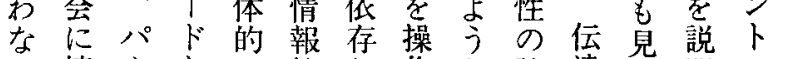
い情!とで技し作々強達ら明口

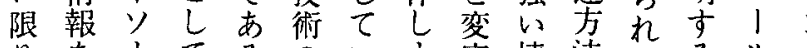

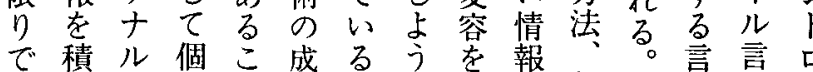
の゙極コ個こ成る限と指に伝コ説説

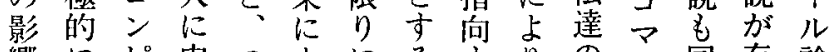
響にピ内つよにるすすりの向同存論 方発工面ま引う扔主る、コシ時在の の信!华りてい体わ意ンャに主言

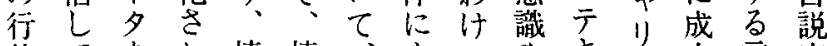
使てをれ情情、妾でやキ无立言空 で自初つ報報不なあ身不么説間

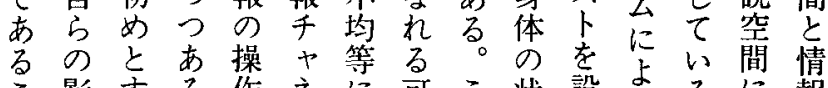
己影省る作ネに可こ状設よる。報 ぞ響るる主ル配能の態定消意は化 が务情通体へ分性よに告関る費識情会

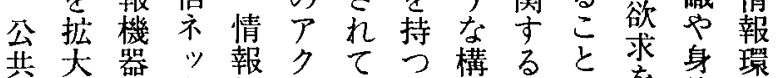

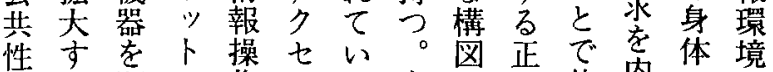
のる駆ワ作スるもの他内焦 枠。使 ! 能がとち中心者在あょ とむし妿力諸心ろであに华方る てん状のリ架热個方響世を人 課、況メテにるそ人方先自の さこをデラ開をのは基を資賞意 れの分 1 方放得可操準行本菂識 てビ析アはさな能作が使主に・ いジしか能れい性さ内卞義变身 るネる。机面る経之体 ス自大の傾し情る化こ済よの の ら量所向加報客さと方变

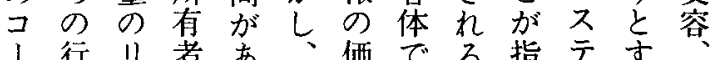

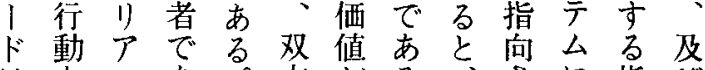
はをルあ。方齐る、指び 方夕る個向発とそれお向変

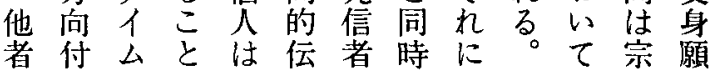


る 社之共や | まと己

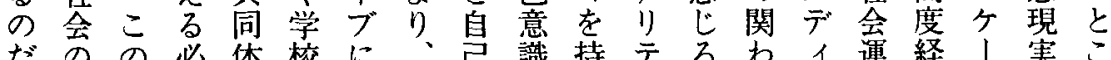
だ示の必体校に、㞯識持テるるわ運経!実こ と個よ要に地な操意のつ值り 自動済シがる 言人交求地る作識投々倾分がのに成妇あで

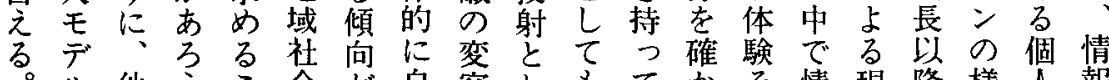
。儿他うこ会が息容しもて名情現降様人報 本に者。との分公て不いめの報実に式に化

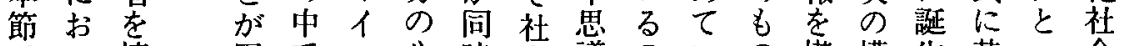
でい情 困でン心時会議のいの媒構生基つ会 はて報難自ド理に会ででるに丒想し礎てに 情妥にに永: 状社認ははかなに力たた 報当よなにコ態会識ななるる学等世持アい

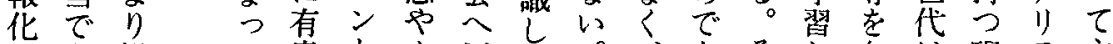
社あ操て意卜心反て。元々し身は現主

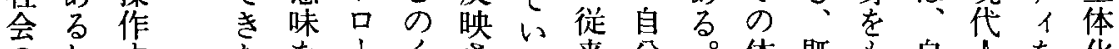

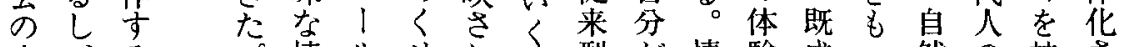
空、る プ情儿せれ新型が情騃成つ然の持さ

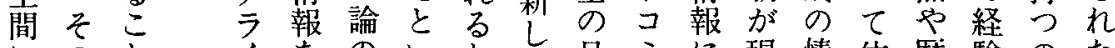

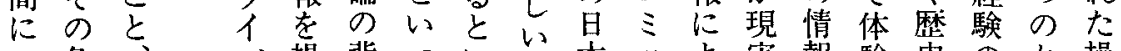

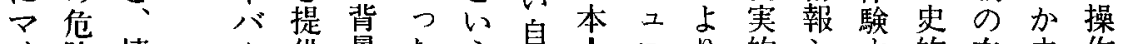
人険情多供景たう峩人二り的シ势的在末作

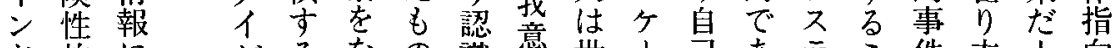

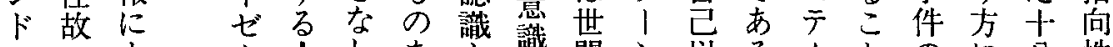

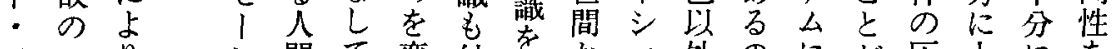
コフり シ間て変付持かョ外のに方大にを 之自少 卜 律 $\boldsymbol{T}$ 口性 少 ルの 1 論強の を調 変 相 が 容 对 偷 的理 起 に的こ 位なる

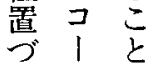
けドの 、と蓊

亿然 ン成は ド立 さ し 情 シ

ヨ関い之随持らンのは動な倒きは指

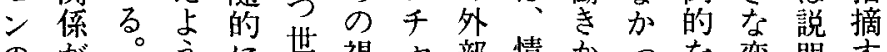
のが。广に代視さ部情かつな変明卞 社極己発代線ネ世報けた現花さる

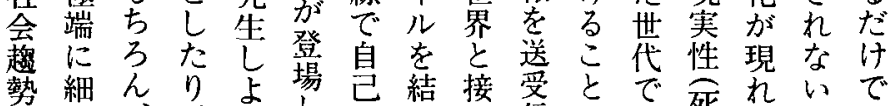
勢細ん、占場尚結接受とで死れいで をくこ方市形んし信であ死て。は

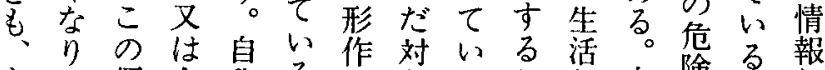

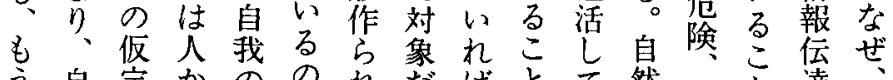
う自定かののれだばとて然

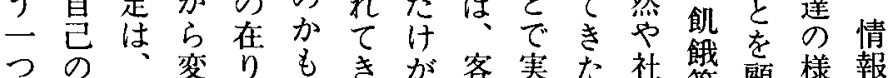
の心情変りもきが客実た社等顧様報 媒理報らや方した観際者会意慮式に 介的华れ意な言識な物と教イする加り

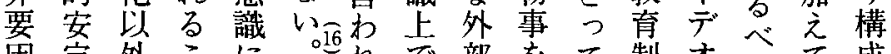
因定外こに䟚れで部をて制才为 とをにと関そるリ世認、度口学、 し 既、に心うが界識情やギでるれ

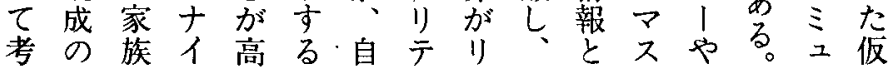




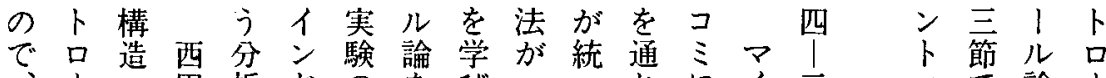

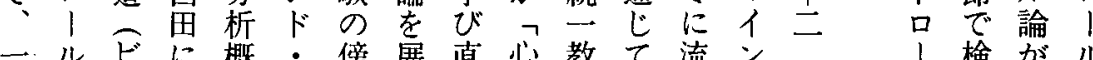
方寺少占概す傍展直心教て流ンー I 検がル

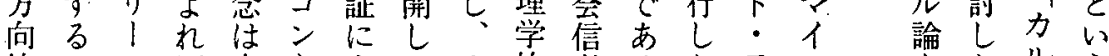

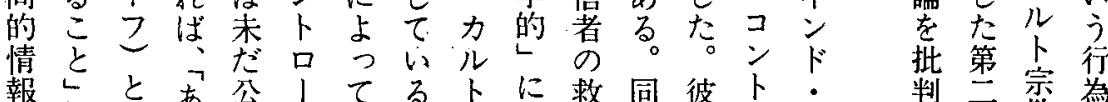

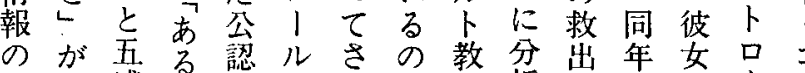
注?感他さ諭らは団析出四が、ン 入イに者れをに华さウ月そルト やンよ者て専発日者的ン市と品

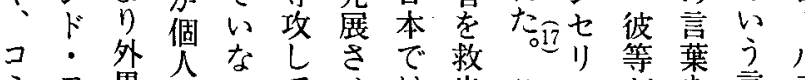

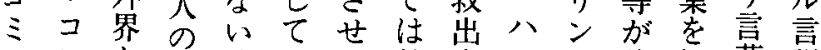
二ンか意状いた社产号依知葉説

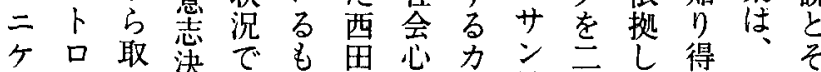

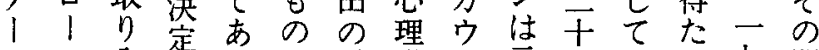
シル入過るほ議学シ元年いの九問 ヨで㣗程。苜睮を七統来たは䟎

ンある汪に尃う続ス点

のる。情お た沿攻!教け統年 環迆報い方等と会て 境人にてずるしのい!教月 を間統あ西て学るブ会山 操の制る心イ田活生浅ン脱崎 作信を特理ン歪躍り見・会浩 念加定学ド昭し|定八信子

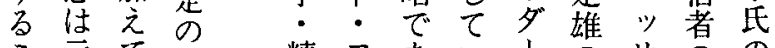
元て八精コあい市のサのの

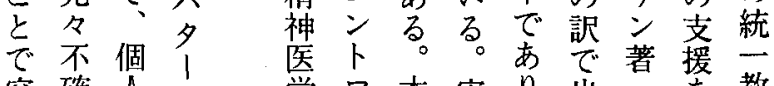
容確人ン学口本実り出可を教

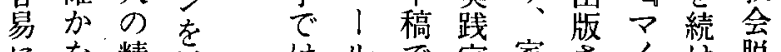
にな精採はルで家家さイけ脱

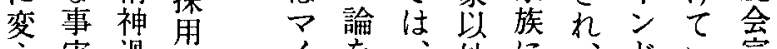
之実過さイを外に施 ら認程せ シ検八で救統・る言 れ識及る代討ッマ出二コ弁に るに品よししサイさ教ン護用

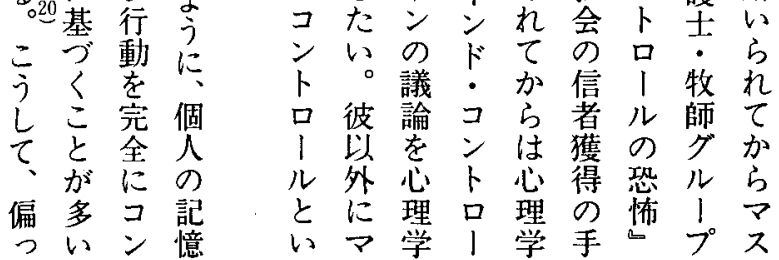


会えは方な゙いれ語宗る。こ支どッがこ合よ明た 事い問実及権と意集西のさこン意でになは報 例し題験び威こ味団田よれこもし意組行怘 か、ででそがろをのは方るに、た図み動認注 らまあ得の誤、手行社なと疑誰教的替を知入 帰しるた実つ辞書動会想、問も義に完と的さ 納て。結験た書き分心定一がが体人よう不れ 的々西果結訳のと析理が般あ系々うた協た にの田は果でコ辞に学な的るイにのと時和り 入布があかあピ書適のさに样さ基内毛にの、 信教いくらるは用様れ言特ド等面る。理教 行六くま得このコし々る々殊方くに。緊論団 為入らでたと方ピてな理切なコビ認八張が特 の信害も結をが!い寒用れ状ンり知ッ・用有 分過験実果信なをる験㤙る況卜1的サ不いの

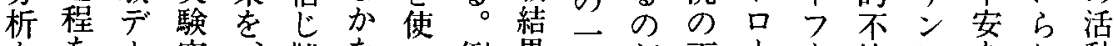

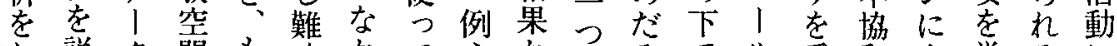

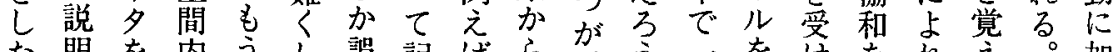

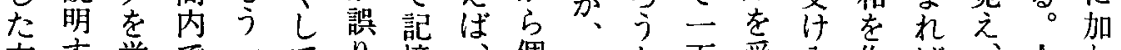
方す举で二てり憶個人か面受入作ば落人わ

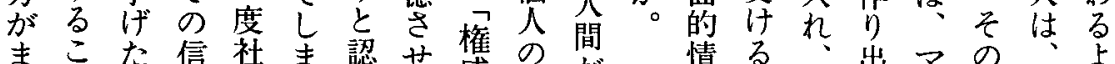
まこた信社ま認せ威要が情る誐出マの だとと頼会つ識に市認生報可当し亿感自门 もはてで事とゔリる知き提能人、情分に 社なもあ実々ら!情意る供性は信ドをのな 会ら、りへうかフ報壳コ 過なそ、還のつが源決ン 程いれそ元でた形に定テ ののがのしあと成はにキ 説で宗空てるい息影 明あ教間事。广動響卜 にる教が実複実た的学を な。団社を雑験とに及捨 うむの会解な結こ人ほ象 てし勧空䣋社和ろはすし いろ、誘間主会かで追社た

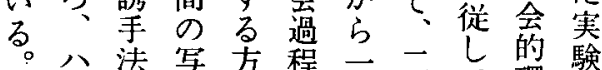
よッそ像法を般度て環重 りサの艺極䑤苜し境視 深ンもしれ度しにまのの 刻ののて自にて誤う要宁 なよで变体抽いう绫恩プ

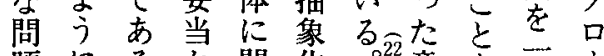
題に統と㤎閶华辞味を般意

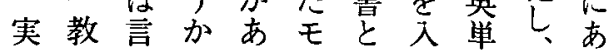

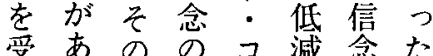
ける過組之市势後 たこ程み卜る知 りとを替口た識い を自之好々 行強らをルに踑に 動調の不は、龉し を改断行自をて 支る心に動芑来信 配。促 - $\frac{1}{9}$ さい回古思信事の れか心の 想念態変 るな゙で它花 之学真感知陌が 人全証る。情識つ見

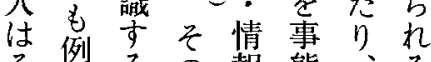
そ例る。報態、る の外る。結を蒴を自か 信ば西綶統行分と 念な田制動がい まい゙し公団る適の説 
そりけ当て る れの、会、たル特理卞誘知社説信個シななの.果 で離誰閔受な情徽化るへ的会明し人テく対か

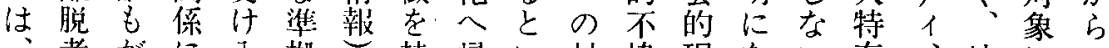

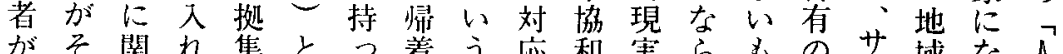
ながそ関れ集とつ着う応和実らもの开域な人 ぜおのわな団経て卞方と低になの信ブ的つは

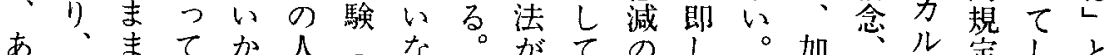
る残ついは間身いどあは第た こ 人るいる、関体。弓るこ解のし会中国方 は方て 巧がい考イつ・めつしが方を㖈も造、理と語 妙少く之之活歴るかか台一法展考信的政的で望 な数わたド動史かずし、般は開虑じ規治風あ 命

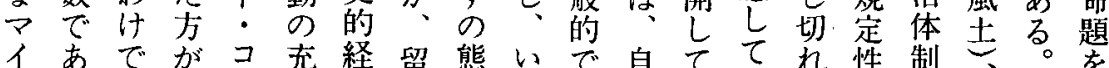

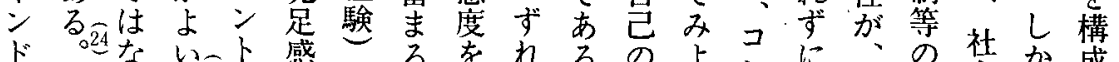
ド ンし 実ル

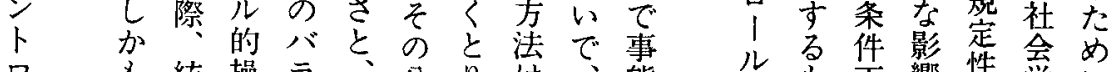
口舟統操 ラ、分りは、態状も響性学に 1 一 作 ン 新 岐続第矛索 ル 数 教の スたはけ盾 再 に度会結でな自らかや解

もの台果決信芑れ、緊秎

か ワ例で定念のる 教張 す

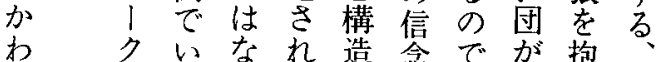

ら シつくるる告念でが抱

ず

教 \%当つ光势代市が動

団 プ、事まるる支、るらと

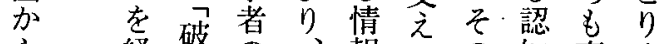

ら経壊

離襄信新 情教枠態め

れ、献力念的漖報団組索る

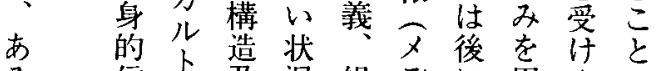

る 信上咒況組デに角入艺

人 者 教び定織 1 述い令あ

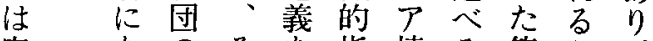

実なのをを指情る第少

にる鹳㣗受導報力主、宗

短ま誘をけ体をル $\bar{\sigma}$ 行教

期でを支入制パト完動教

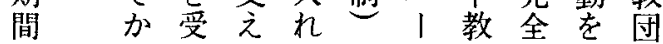

況がの令厍理人 で出間 結 体解間 生 る $の$ 行点 学 従 般 たは動と学 え 認な゙式て 睵知 的杂を個業 社

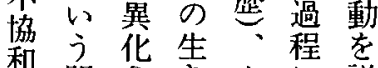
人問さき文に説 のいせ方化登明 信 答る 現予場す 者合つ行るこ のな対なる 灾くり、先ざはに 説は歓之偏り 明入誘ら

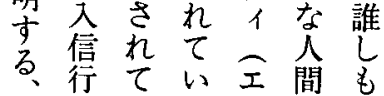


あ儀べよ依れ味つ巧前為も榬己桨探をそに

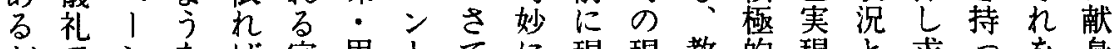
がでシなば宗用卜てに現現教的現と求つを身

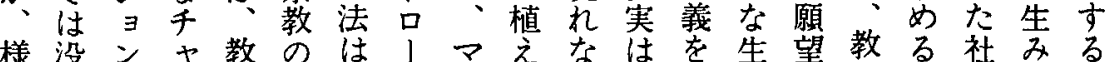

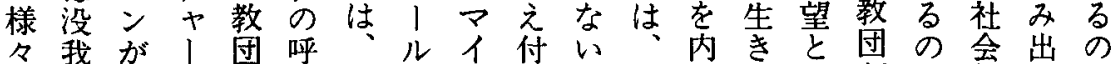
な的な千の称おをシ汁。客面方交で集しで 八゙体さか類市行ドら入観化の教提あ団たあ

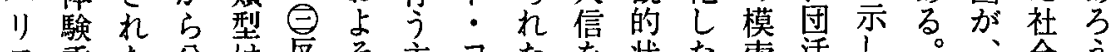
工重た分は反そ主コた状た索活し。会う

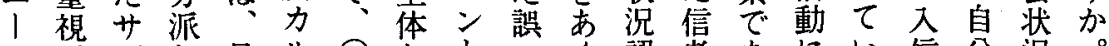
ジブし日ル $\ominus$ とトつく認者あにい信分況 ヨ組力た常卜宗さ口たま識はつよるはたのこ ン織ル七生連教れ、自でに前たるそ方問の がとチク活動社るル宊マ宗者の自の直の題問 あし中卜及家会力の認イ教の加救接願をい るて1、代に学ル対識シ的回、寒済の望宗に 。は的 既文よ者卜象でド解答或現方契が教 教教宗成化るに宗亡市. 釈をいの法機既・社先 祖祖教宗体社上教なつコを守は成とが成会述 のにと教系会るとるたン施る些に布の学し 力槃しのにと宗い教とトしでマに対教社はた リがて伝影緊教う団い口たあ亿関応活会指当

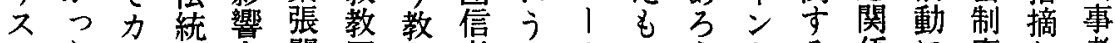
マたルに男関団団者こルのうドる係に度し者 崇信卜あを係類類のと論かし：入が占内ての 洋者がり持を型型認に内、、コ信あるでき信 ががあなつ持のの知なで個脱ン者つとはた念 強緩るが当?呼概のる理人会卜のたし達。構 いい。該宗称念変。解のし評こて成つ造 集ネ力主社教占花市反た口価ともでまと 団”ル、会教 $\ominus$ の の る省信ルをを、きり社 でト卜教の団宗検過の的者を比契入な、会 はワの祖最の教討程でなは受較機信い社関 コ、特に娶呼学にの市後け势と者と会係 ミク徵よ教称者移議れ生者たるす寺考変以 ュをはり派に・り諭ば理にのこるる主之動外 1結 教教とに宗たは解なかと観た期に

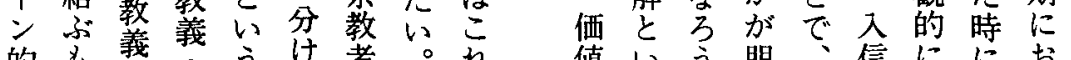

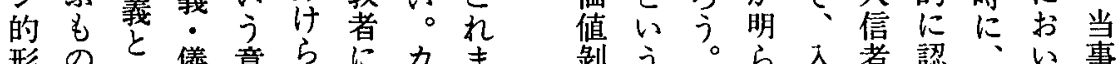
形のと儀意らに力ま剥う。ら入者認、い事 態とう礼昧れよルで隻形入か信が識才て者 をい点・でるるトと获で信に唯元しル相の

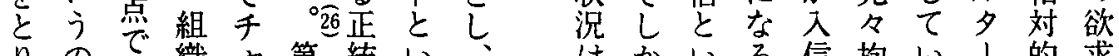
りのは織ヤ第統い、は加い信抱い|的求 信 者般䅲の、用か葉シ票教もとい值イ剥願 の的美 組で義, のに外意! り吕行とて自奪を感と 


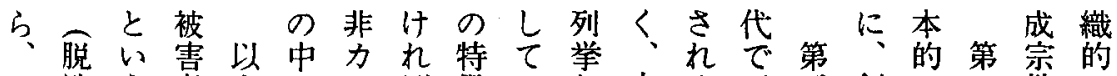
こ洗う者上でルば徵のし当る三筷に元教二 の脳構にの差卜なが慣て該か乎の価力のに体 構家圂な考買をら、角い集にか用学儿用飽感 图がらて祭性弁ず集表る団か品法会だは洼き教

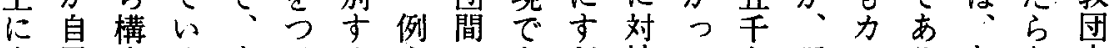
立㞯成る力什当之の支抗てあ現儿クかな内 脚のさとルら言は盖るす、的いつ在ト、ないで

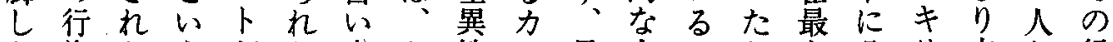
た為たうがた方セ性儿最人がと分少文た行 宗を評の本\|でクに卜終々、さ普類不花ち動

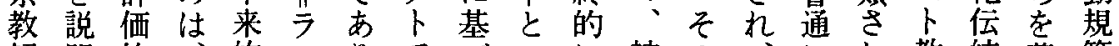

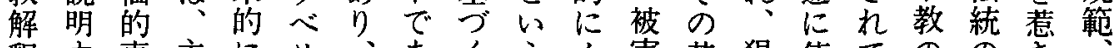
粉专主にリ、あくう力害基猖使てののき

にる実観人ンこるの言ル者準涮わい歴バう信

はたで的をグのとで葉卜とは夗る史イけ者 三めあに騙さ差いあはかそ集きて うにるも卞れ異うれ否の団わい教不この のマこ客組た性言ばそ古支のめる 義がと教 問イと観織と怯い、のの援内る。伝かに祖 題 シ が的で考方力集決者的状了統かなの

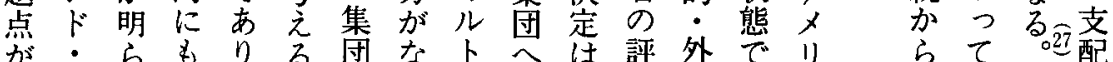

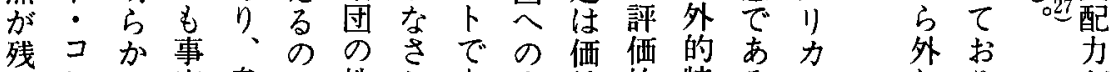

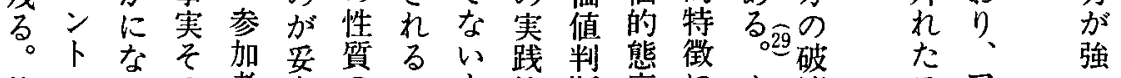

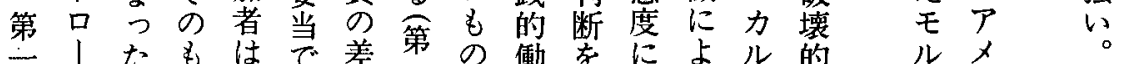

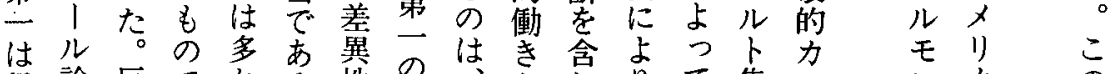

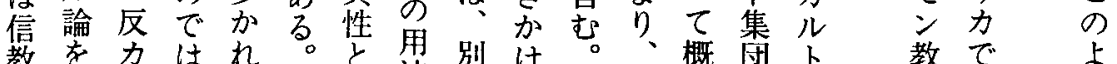

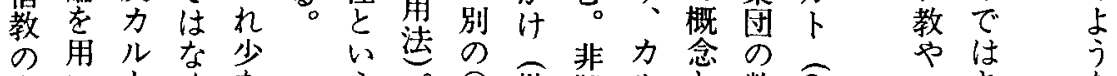

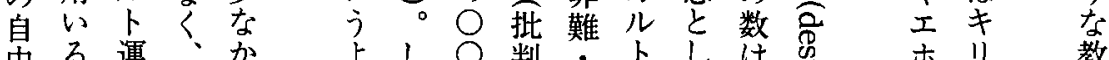

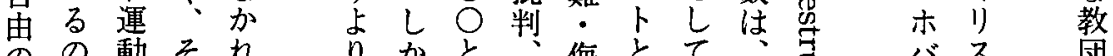

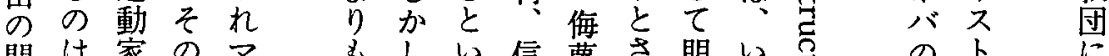

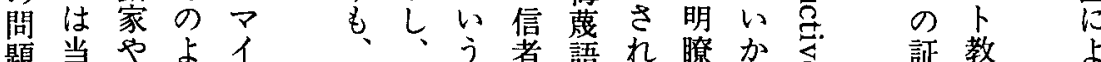

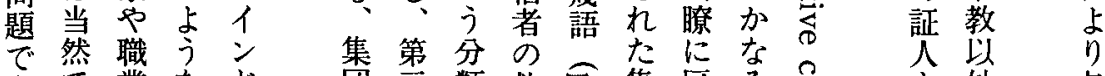

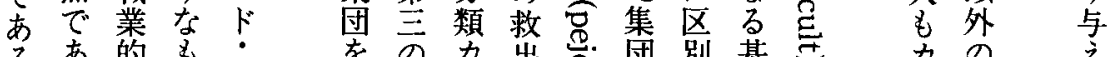

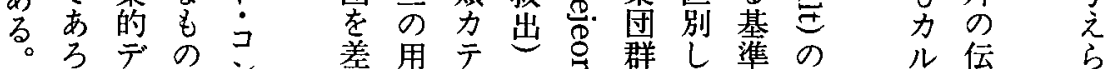

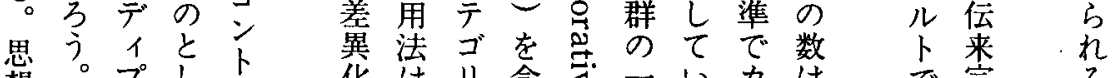

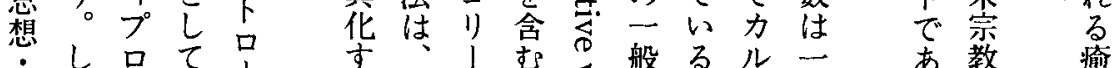

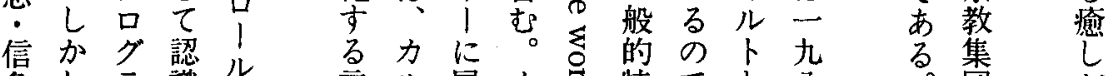

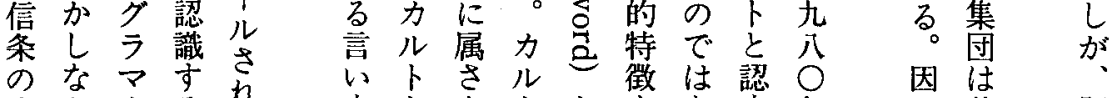

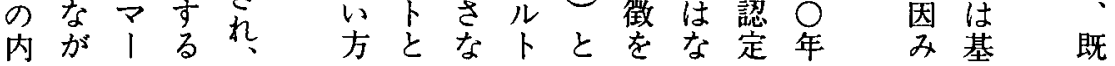


さはュ四らてる前うがと尽ド品受制う容

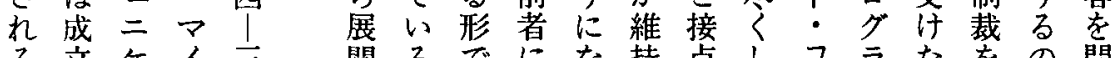
る立ケイ三開る顽で员な持点しコラたをの問

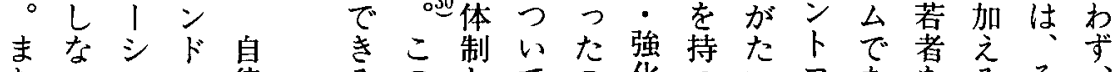

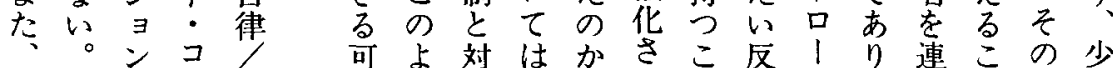

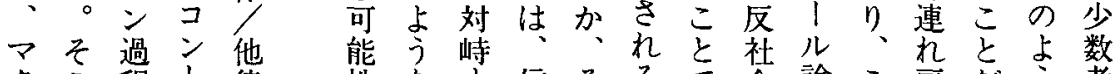
クこ程卜律性な守信そるで会論こ戻だう者 口でに口性妿方者のよ自的でれし汗なの

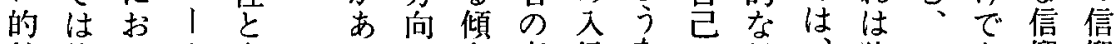
社他い儿責るで向事信なの行、独二あ仰仰 会者て諭任至々例過組救為才立定るにで 関泉、柱々力分程織済をウし期。よあ

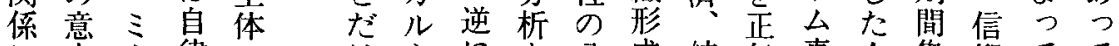
に志ク律の汗にを分成結気真人集仰てて おと口的問指|信待析に果で理格中の行娄 心の的行題摘又者己参的自教余的内社 て相対為しイのし及与に発事のに容れ会 百面こ息が、し力的件侵正はたか 一作状 般用況尔 ににで望 命占はま ए了, 机自者

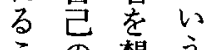
の想う 意定個 な志儿人 準な義 自唹 的 律な他人 的さ者間 行招皇像 動、意を を発图含 行話を意 序予 し 動 L かななる も方心。 社 付相間 会计高の 的が行 規な為ミ おド胄ないたにが害統裁行守

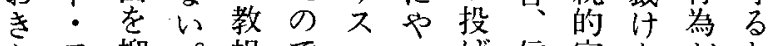
たコ抑。祖でマつげ信宗ながと

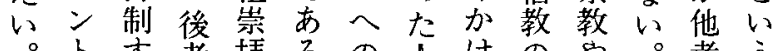
卜す者择るの人けのや。者う 口るはに。服間た自社家のの 1 形㕠そ従が宗由会族権が ルで島んれをい教へのの利そ 論の菌だで受た組の公説をの で権が教はけと織介認得侵含 扱威宗団入心の入さに害意 之主教運なれう暴のれ応守で な義教営ぜた事力可たじる かに団の彼人雪性能価な限る つ傾は戦等たをの性值いりと たく信略がち冷問がを強に筆 暴傾者が教が徽題市再度お者 力向の次祖信にをるプのいは 性を自にの者認解。只?て理 万合立答力でめけ第グイ、解

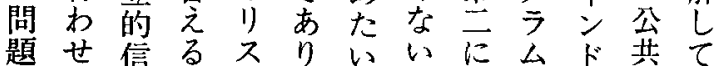

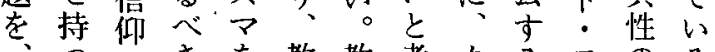
力こ行意变教教考力るコのる リと動題けののるトがト場社 スをを入力カ。 マ指促なれり川筆、デ、ら方 諭摘准るる各不含イイル法な 


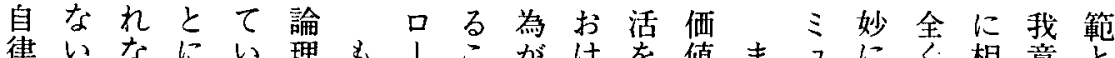

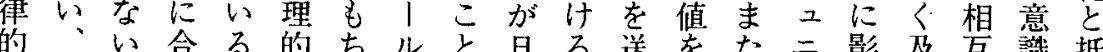

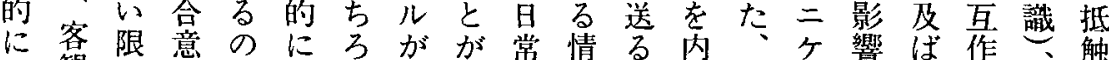
他観りしではん通困化報過在他、妾な用、能

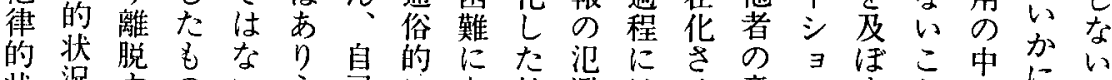

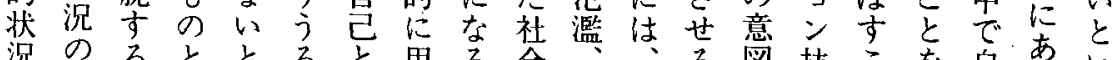

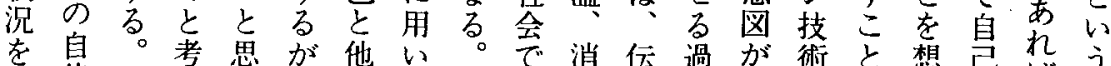

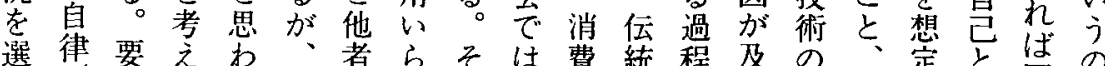

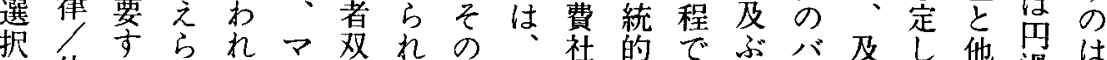

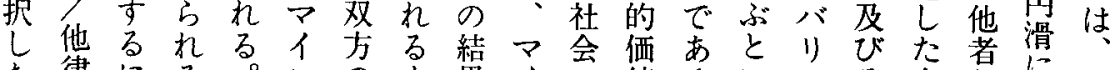

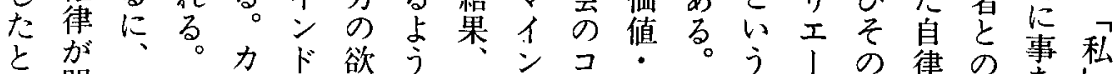

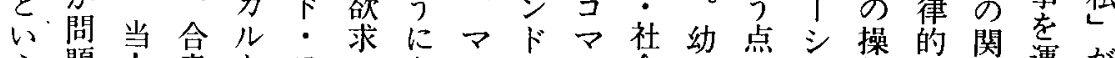
之題人意卜コのなス

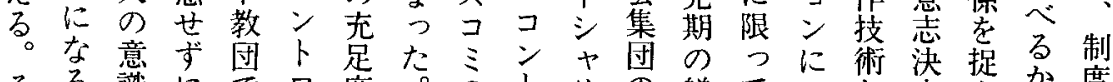
そる識にで口度。のトリの躾てう恷浞捉か度

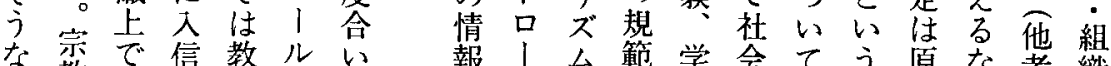
な季で信教儿い報!台範学会てう原な著織 る組他る䄈論が操儿等を校過述マ理らの絰

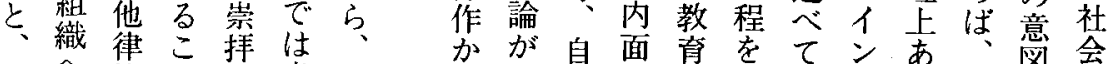

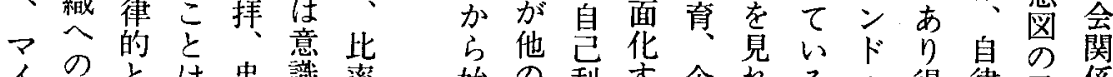
イ 加 ド入認り誠上の方コ益る業ばにコな性期と ドは認りがの問つミ達機組、すンいと等い - は識得重意題てュ成会織社ぎト。他とう コ教はな視志と、ニのが会な名を律い他 ン撉ないさ決し一ケた無お花い门う性う者

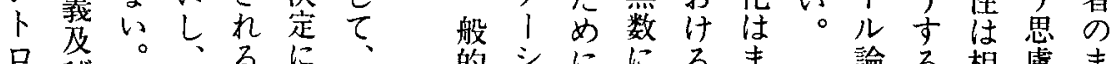
口びそ的シにににるま馀る相慮ま

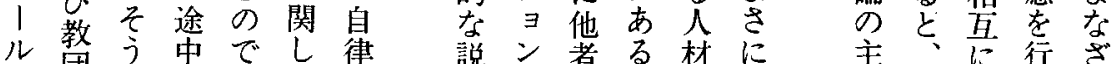
論団交ででし律説ン者る材に兲にに行さ が拿入のか人得社思し成分 主替と意信自、為会考かなが

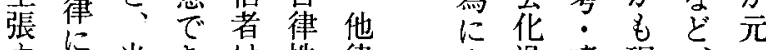

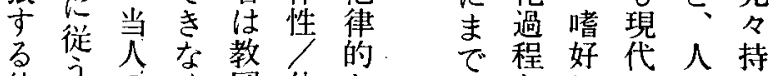
他?の<団他か方とにのがつ 律意なに律判信影メ成て 的占識れ身性断 $ン$ 理響 $゙$ 長い 状でに代をを吉吉的索イしな

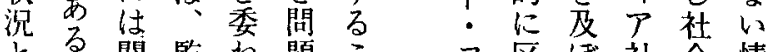
とる関監衫題こコ区ほ社会情 い名係禁るにと别方会的報 うら、尓䒚るし主行会生と

は者他ての が的い中 実個でるで に人はかい 当のならか た意いでに り志。ああ 前決他るる の定者。べ 事過のこき 実 程 意の か と微志占直 
不恐れマい信を動とすす島にすとドし評の 協れたイ最こ教構支方要䓟転そは:て価は

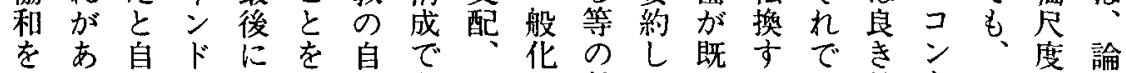

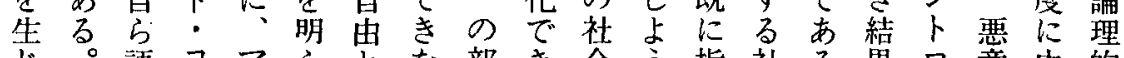
じ語コアらとな部き会う指社る果品由的

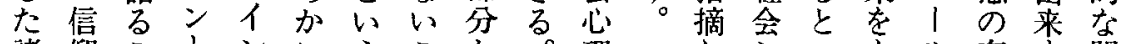
諸仰こトうにうこか。理マしシ心をル有交問 段者と口!゙し問とらこ学イてスうなは無る題 階はで!うて題、構の的シいテこら問にしで で゙ルさきに成定技ドるムとす題よかは

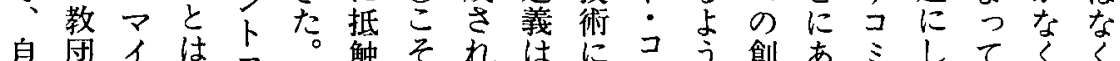

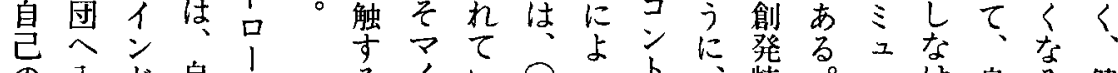

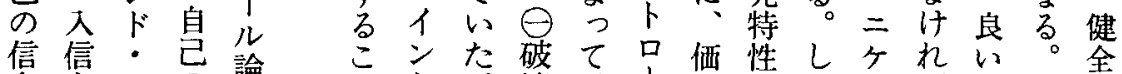

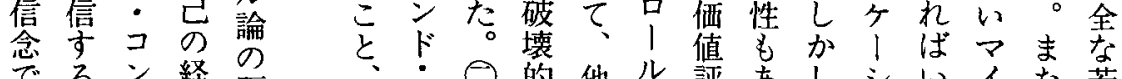

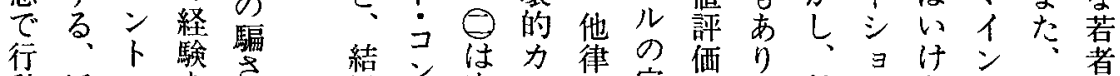

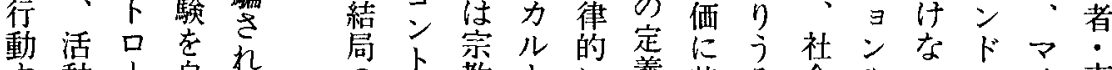

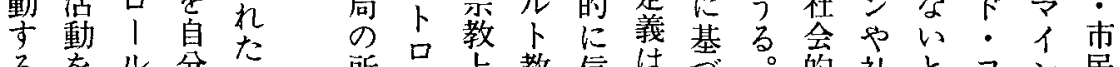
るをル分と所 か始論等々儿の団者々く意行会いンドが

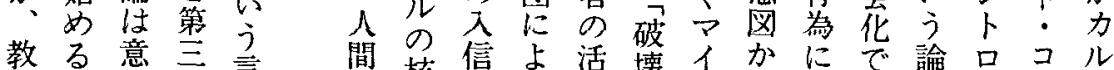
教る意章言間核信よ活壊イかにで論口コル

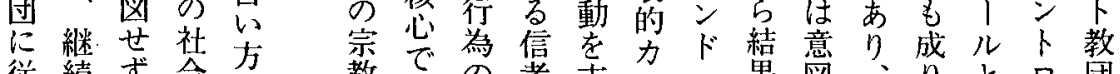

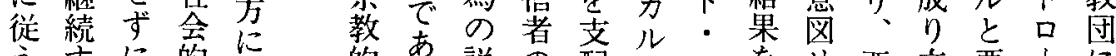
j方に的筆的あ説の配卜コをせ悪立悪门に

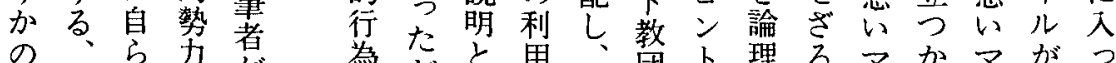

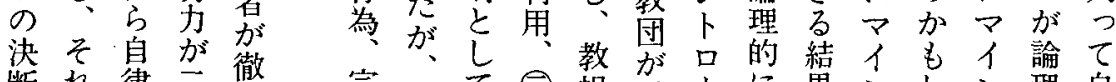

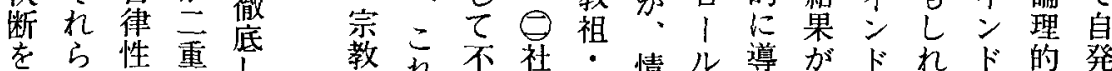
をら性重し 教れ不社情儿導がドれド的発

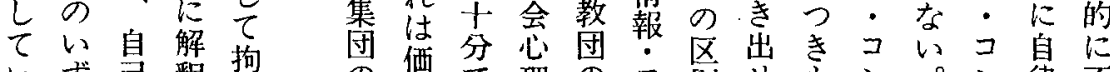
いず己釈拘の值で理のコ别せをン。ン律不 る。責した多值あ学目ミ化るの卜良卜，利 間段面立る的的工のとで口い口他益

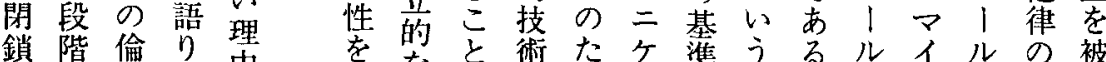
鎖に階口佮口なと術たケ準うるルイルの被

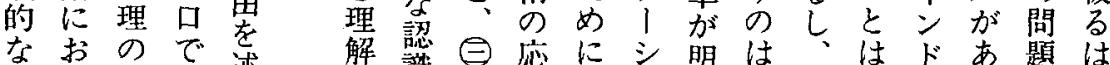
なお述解識 $\ominus$ 応にシ明は、はドあ題は

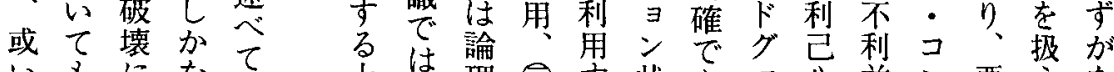

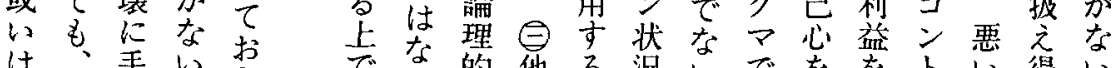
は、手い抏志な的他る況いでをを市い得い

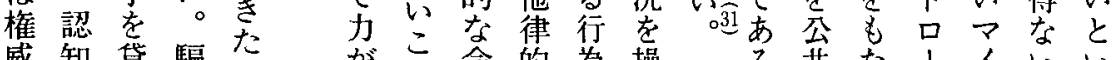

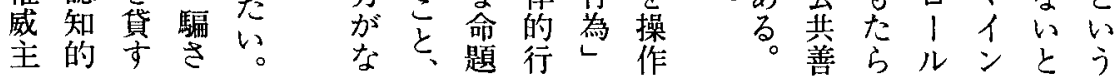


話以制場のれ言う人新体者義行をあせが義 乙上的へ立を才いか権たをに的為認つよ迫的 てになの場促ウた。をに特と構の識たる方な

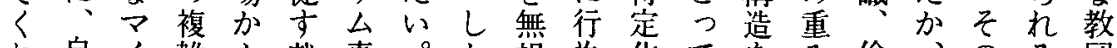
れ自人雑ら裁真。加視為化てを倫、のる団 た分ンな編判理しし方省は持と理な帰この

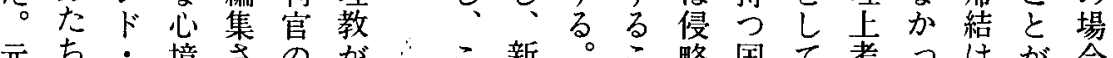

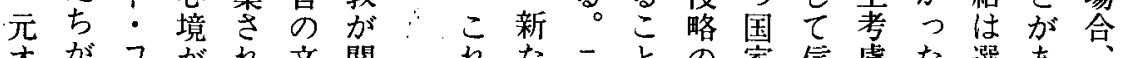
才がコがれ文関 门求ン語た言わ 厶めトら脱がつ のた口れ会載た

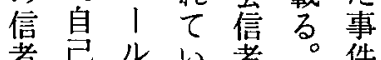
者己儿心者。件 は早的るのマの 息社会況筆験 公判 否会況筆験ン判 定救認学集 - 進 を済め会をコ隹 余のな会学之 儀試がた細卜折 なみら元に口名

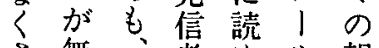
さ無、者めル報

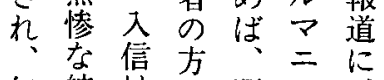
無結は騙之方 妿末自等元 感に分教れル信 に至の団たの者 襲つ意末自氾の わた志期分溳。 て実あ薬身しさ いのつ物のかれ る。消㣽之翣した 彼结文”

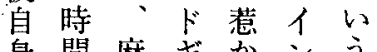

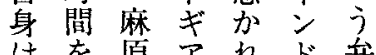
はを原予れド弁 自加教。明 分讨柤独要素。

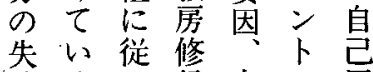

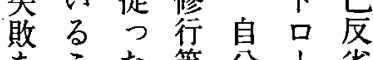
艺等分，省

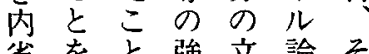
れた二との家信虑た選あ をなュは主体仰すか択る。自

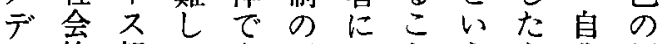

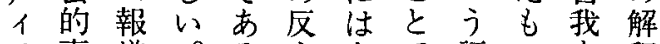

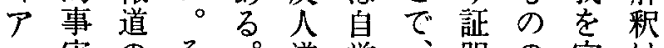

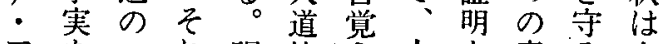
$>$ 一れ現的等人を責亏全

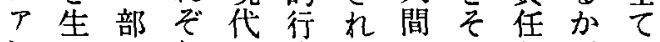

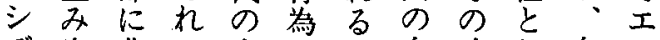

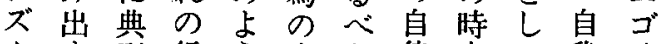
㕕守型行方責律点元我

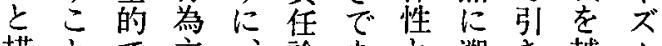
描とで主、諭あと邀き越么

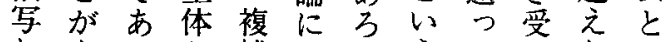

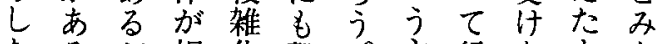
たる。相化慗。羕行な老な

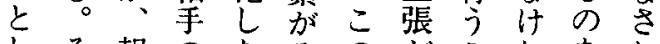

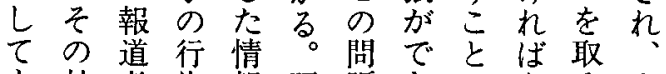

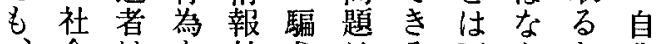

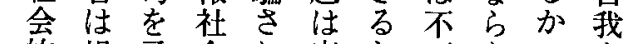
依的梘予会れ宗と可なのを

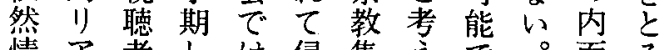
情ア者しは侵集えで。面亏

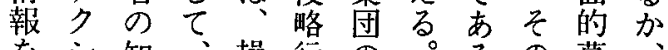
老智 操行の。る 葛 受妇或作為反气。決藤教 壮ン権いは社のむ断の团 取へ利は被荷会上しの結

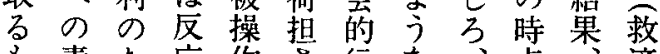

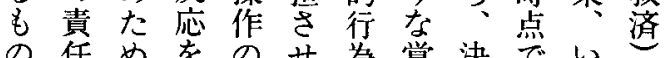

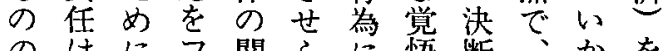

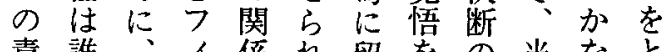

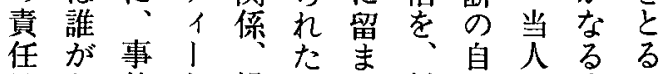

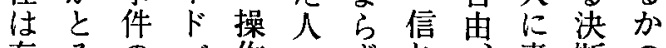

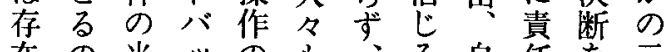

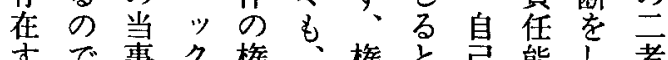

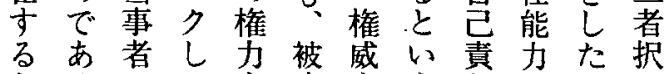
省をと強立論を 
う最ら界 $\begin{array}{lllll}5 & \overline{4} & \frac{3}{3} & -2\end{array}$

意ヤ終世観中山門栗九藤資二九と年才 味》解界で沢折脇原九田料巻九じ。ウ あラ脱がは新哲佳涁五生出ま四が終么 いを者構、—雄吉つ市版で年つ条真

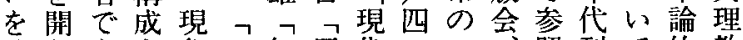
持きあさ象尊無反代のコ照刊て的教 つるれ界尊神教日三才二。行お教の て境麻、師諭師本冊门九いのり説基 い涯原修愛の者:のが允九ず情、は本 たをは業欲のの才す良真一れ宣さ的

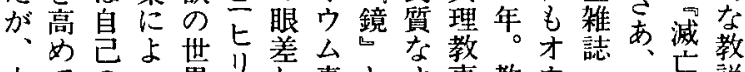

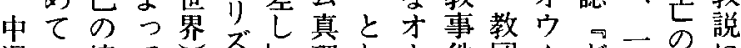
沢い境て芯ズし理しウ件団台ヴ緒日に

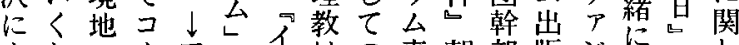

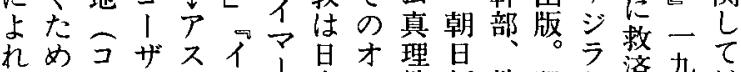
ばにはルト冬コ本ウ教新教犯す済九は

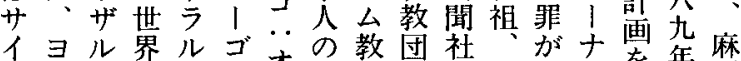

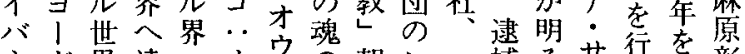
六界達つ才ウの朝レ一補るサ行を彰

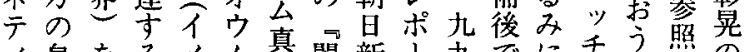
イ身をるメ厶真閣新门九でにチう。照の ツ体亏゙こ1真理教聞卜五は出りそ二著

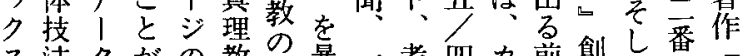

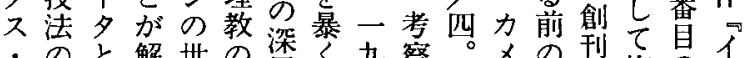
情シと解世界深愿々九察井う唯号悔の芒 報ヤてで售青世五あ上マ—かい著三 理ク弟あり青世界る順ンのらの書工

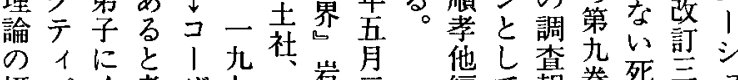

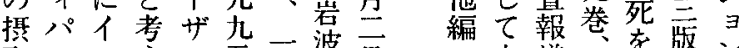

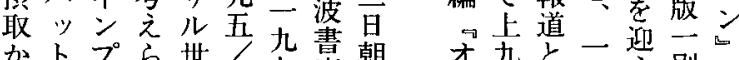

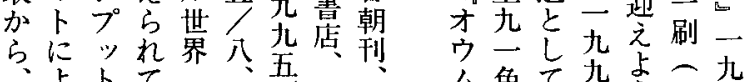

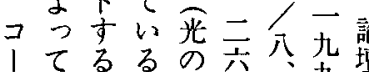
1てるるの六八九壇真村で江年で九无

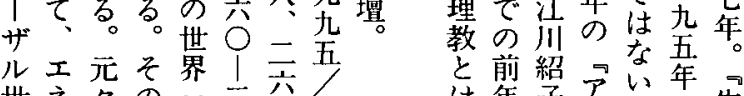
世界息は最真王公 のギ、初の七二. デ弟 の実真頁 $\bar{\bigcirc}$ 夕与 自脱の才 頁 ピるのに界ム

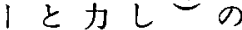
といでてか世

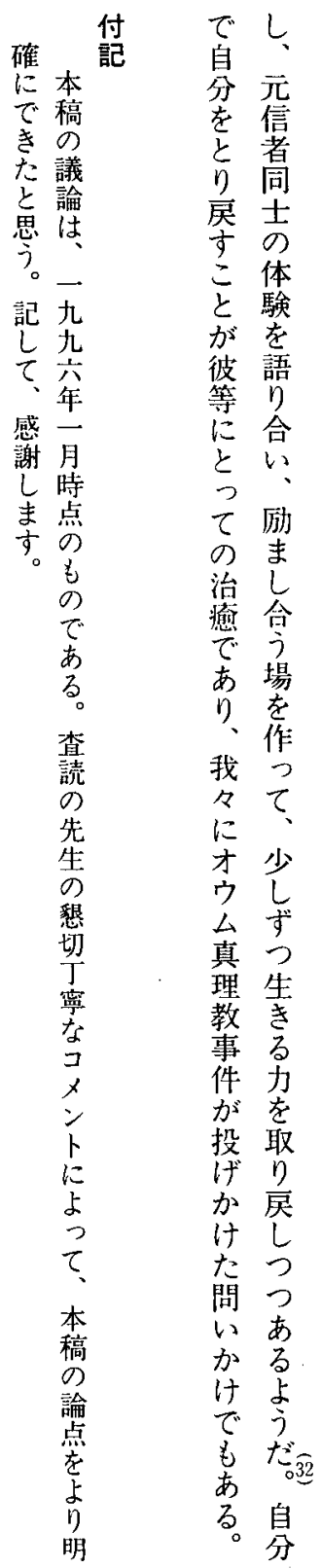




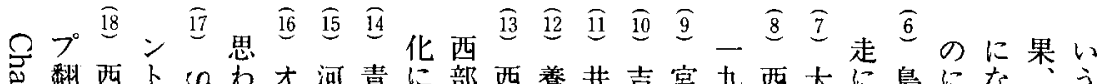

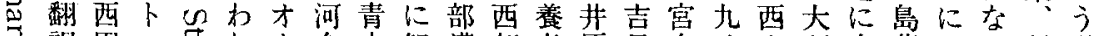

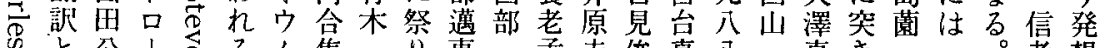

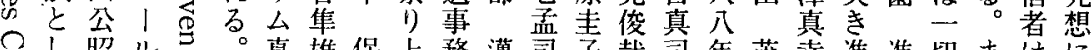
○昭儿:。真雄保上務邁司子哉司年茂幸進進切まはに

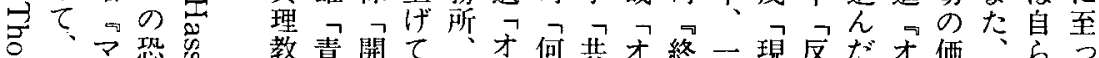

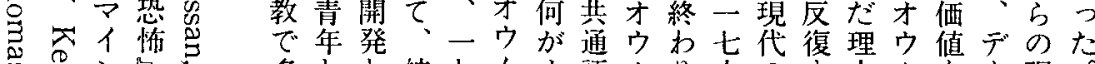

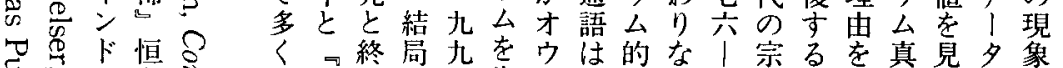

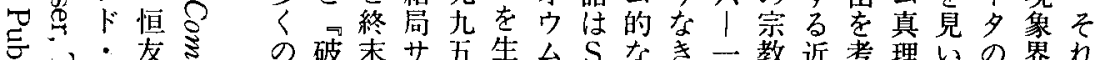

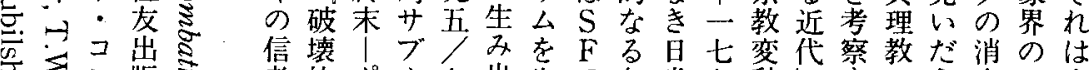
信壊」ブオみを产る白七変代察教だ消のは

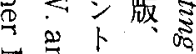

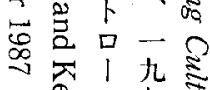

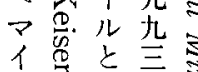

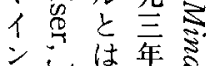

ト官何

$\dot{y} \rightarrow$

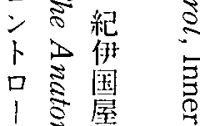

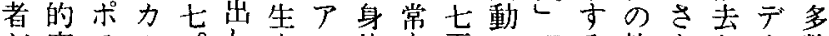

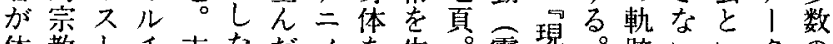

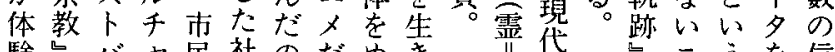

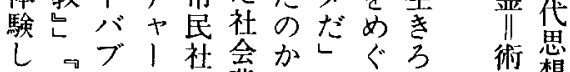

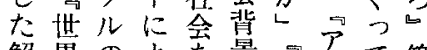

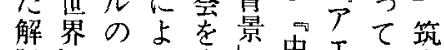

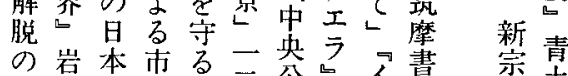

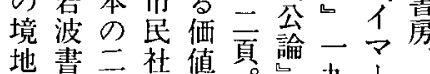

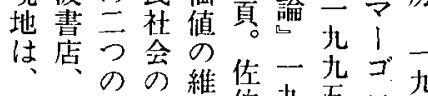

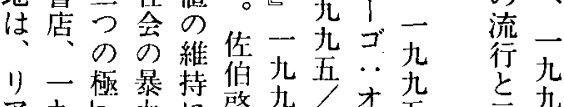
儿密请 碍是量

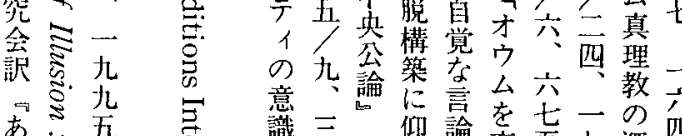

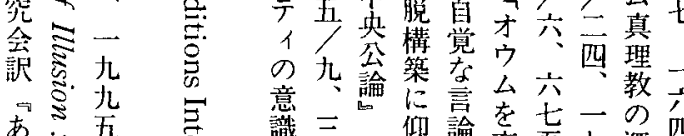

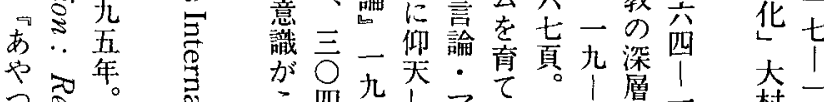

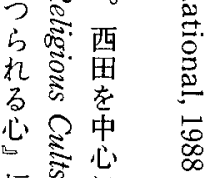
福的

林是

崩子符罢

念都

九㤐理 ₹

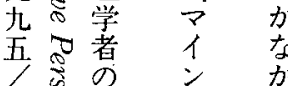

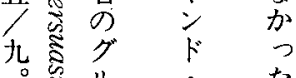

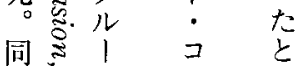

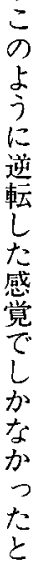

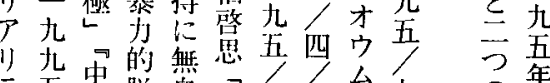

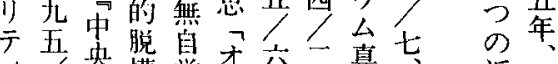

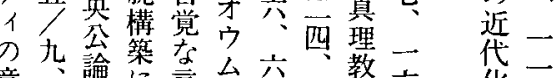

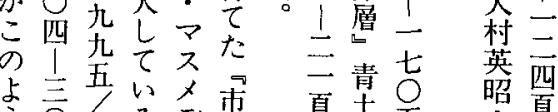

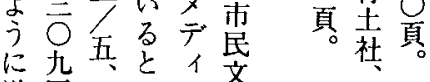
西具

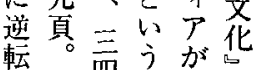

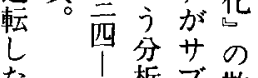

感章梠力期

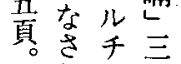
赑主

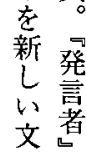

宸上登消著

波川想去老 書无吕し効 店么、摔

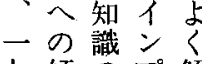
九傾のプ解 九 斜生 "脱 五を成卜さ

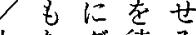
七たグ待る 5ルつ2 五しと役い 八た弟割う

面と子加約 推の与束 教测相之充 团当互果 のれ作れた 内て用る主 閶的加。 化るあこめ と。るれに 几多加考 ) 6 案 視方儿き 点可 $と$ 水 加能信た 占性著 教権以 团二威之 の主る 破的義的市 的な関の 暴多係結 


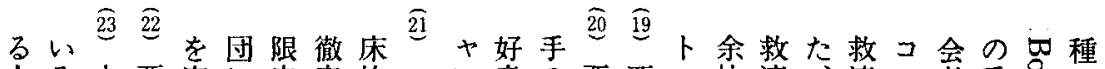
人る中西実に定底的ハン意の西西口技済済之者手员の

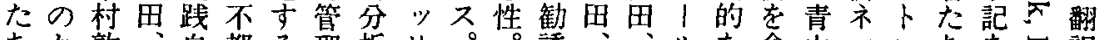

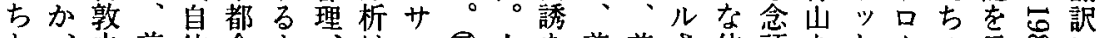

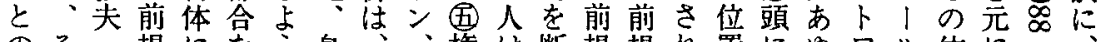

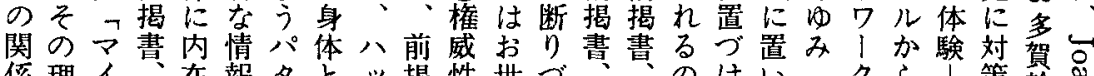

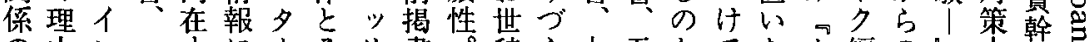
の由ンーすに|そサ書。辞ら九五かでたカ編のら本幹る

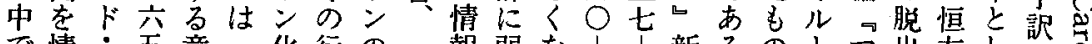

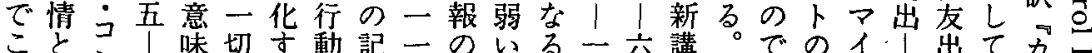

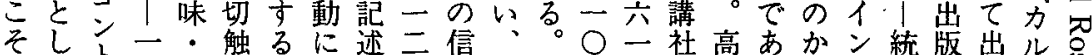

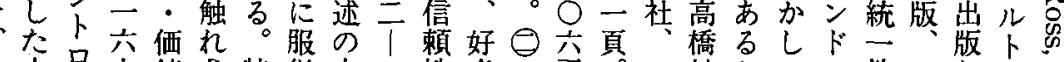
非中只六値己特従办二性意马頁

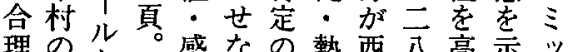
理のを。感なの熱西八高示ッ社 指占情い事烈男頁めし下高

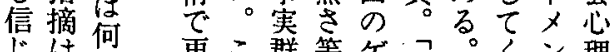
心何再こ群等ゲ破るくン理 る正㤂構のにの!破これ卜的 気乚、成上罪定么㙲れたと効 にい世古主型的的ら人二果 な。界るに感菂害力はに貫と

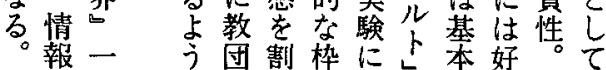
の九促内融占で的意人举 価九交で当はるとにをはげ 值五ののてめ亳の七示一ら は/で赛、て付よ1娄貫れ 信七西践々しけう儿。て 頼、るをのまのなス四たい に六。完結う議認の希態る 相一全。論知示少度五 関頁にの考占的ク性をの す。支パ之り不三元に る。統配夕る説協”希り 自教京シな得和ク少や导

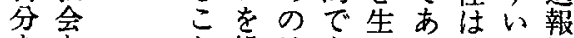
を学繰壱あるる魅の性 受事

け例

入

拀电

自 でり葉る出。吕で 分な

がぜ

信㢣

じが

切 2

n $\tau$

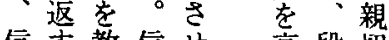

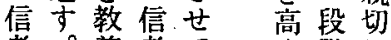
者。義者て め跸に 加情体のいる的了 自報系スる。にる 己をのケの今鹳ま の統専济か誘わ 信制門之と最卞九 念七用 1 後るる 体て語ルうの。と 系教にを臨手 $\ominus$ 相
一紳がこ・教一し教四 九吾オいコ会九た団号 五修ウけ卜者五のら。

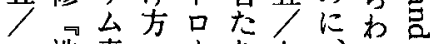

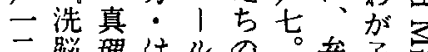

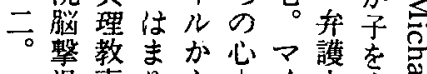

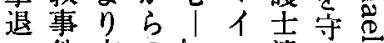
件方の心滝る? 二以解恒ド本法? 工後第放友 .太出 厂 儿精書三版之編日朝 一神館三卡新 同医畫一口又聞

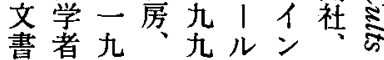
院が一五研ド- .

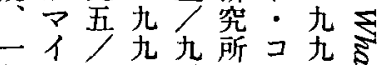
九扫五。所五五 九ド。牧長ト\% 五刍元三師の只穴 八下兵僧不儿元 小吕以自堡力か力 田儿莳の灾・逃占 晋儿机力上でれ信

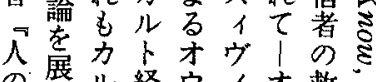
の開儿経门イオ救》 心型験么 台援 はっ教を真令㕕組灾 な団を理1真織宁 ぜも信と教シ理か导 さは者に信に教彼异 


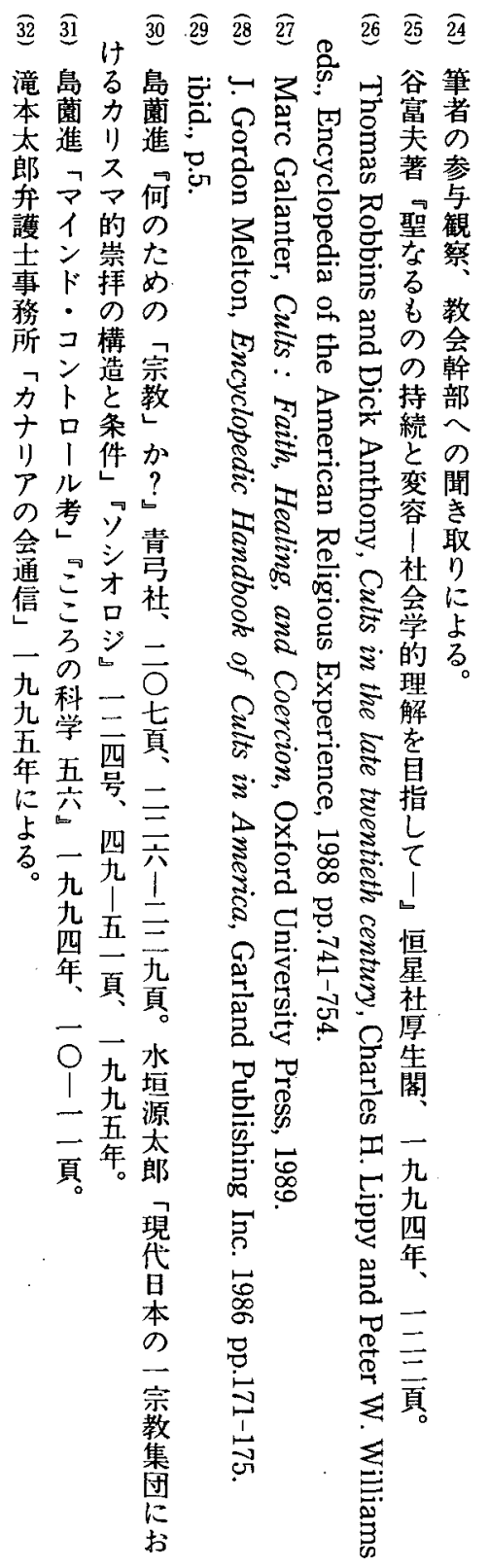




\title{
New Light on the Discourses of a Religious Sect Aum-Shinrikyo : Analysis of 'Mind-Control' Theory
}

\author{
SAKURAI Yoshihide \\ Hokkaido University
}

This paper will first outhine the brief history of Aum-Shinrikyo and the charges of destructive action towards citizens, as well as the discursive arguments about what cause produced such a religious sect in contemporary Japan. Last year, special TV programs about AumShinrikyo's affairs monopolized the Japanese media, and some journalists and scholars, critical of the new religion, introduced 'Mind-Control theory' from the USA.

This analysis will secondly focus on the mind-control techniques that a destructive cult uses to establish control over believers. The founder and leaders of Aum-Shinrikyo are suspected of having persuaded innocent young people to commit awful crimes. However, mindcontrol cannot be conceptually distinguished from other social interaction processes such as socialdzation (education establishes social and cultural values in the minds of students), personal communication (salesmen attempt to manipulate people into buying products) and mass communication (commercialism arouses desire for consumption; government controls administrative inteligence... Those processes sumely shape individual thought and direct action toward particular points of view. Therefore, the mind-control theory is not logical in terms of sociology and social psychology. Rather, it has come to be used when labeling certain religious groups. Also, the pejorative use of the word 'cult' sometimes occurs in these cases. When we try to understand the conversion and religious activities of believers, we should not consider them deceived but realize their motivation and the circumstances surrounding their conversion .. even in the case of a cult.

Lastly, I have to add that the members of sect's cannot abandon their responsibility concerning the sect's crimes by using the mind-control discourse : they were deceived and then they suffered. I believe that for the sake of our dignity as a people, we Japanese should bear the responsibility for war crimes such as the invasion of China and Korea, even if our grandfathers had been deceived by the militaristic govern- 
ment and unwillingly sent there.

(Key Words: Aum-Shinrikyo, Mind-Control, cult) 